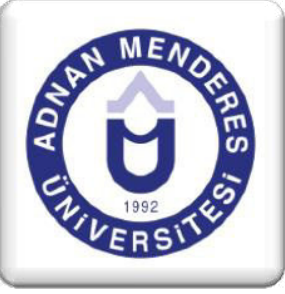

\title{
Büyükşehir Belediye Kanunu'nun Kahramanmaraş İli Ölçeğinde Analizi
}

\section{Özet}

Türkiye'de şehirlerin nüfus ve mekânsal alan olarak büyümesi ve toplumun belediyelerden hizmet beklentilerinin artması, belediye kanununda yeni düzenlemeler yapma ihtiyacını doğurmuştur. Bu nedenle, 1982 Anayasasında büyük yerleşim birimleri için özel yönetim birimleri kurulabilir hükmü getirilmiş ve bu hükme dayanılarak 1984 yılında ilk defa büyükşehir belediyesi (BŞB) kurulmuştur. Daha sonra büyükşehir belediyesi ile ilgili birkaç düzenleme yapılmış ve son olarak 2012 yılında 6360 Sayılı Büyükşehir Belediye Kanunu çıkarılmıştır. Bu kanunla birlikte 2014 yılı yerel seçimlerinden sonra büyükşehir olan Kahramanmaraş'ta, belediye sınırı il mülki sınırları ile birleştirilmiş, belde belediyeleri kapatılmış, belde, bucak ve köylerin idari statüleri kaldırılarak tüzel kişiliği olmayan mahalle statüsüne dönüştürülmüştür. Büyükşehir kanunu kabul edilmeden önce sadece şehir ve kasabaların mücavir alan sınırı içerisinde hizmet veren belediyeler, bu kanun ile beraber kırsal yerleşmelere de hizmet vermeye başlamıştır. Bu değişiklik belediye yönetim anlayışında bir ezberi bozmuş ve merkez (şehir) yönetiminden mekânsal alan yönetimine geçilmiştir.

Kahramanmaraş Büyükşehir Belediyesi'nin hizmet alanının mülki sınırlar olarak belirlenmesi ve belde belediyelerinin kapatılması ölçek ekonomileri bakımından olumlu bir gelişme olup belediye hizmetlerinin etkin ve verimli sunulması yoluyla hizmet birim maliyetlerinin düşürülmesi sağlanacaktır. Fakat il merkezinden yüksek ve sıradağlarla ayrılmış kuzey bölgelerinde hizmet maliyetinin artacağı, görev, yetki, sorumluluk, temsil ve katılım açısından önemli değişiklikler ortaya çıkacağı belirlenmiştir. Kahramanmaraş ilindeki belediyeler arasında değişen görev, yetki ve sorumluluk dağılımının rantabl bir şekilde sürdürülmesi mümkün görülmemektedir. Büyükşehir belediyesinin yükümlü olduğu hizmetlerini sorumlu olduğu bölgelere götürmesinde ilin coğrafi büyüklüğü, topografik çeşitliliği ve mekânsal uzaklığı hizmetlerin kalite ve birim maliyeti kadar hizmetin ihtiyaç olduğu zamanda ulaştırılmasını da etkileyecektir. Aynı zamanda şehirler için hazırlanan belediye mevzuatımız ve hizmet kültürümüz kursal alanlara hizmet vermeye uygun değildir. Bu nedenle Büyükşehir Belediye Kanunu ile belediye hizmet alanına giren kırsal bölgelerde kırsal politikaların uygulanmasında yeni sorunlar ortaya çıkabilir. Öte yandan yerel yönetimlerde yetki, kaynak ve ölçek büyüklüğünü artıralım anlayışına dayanılarak yapılan yönetsel dönüşümle ve bütünşehir/büyükşehir düzenlemesi ile ilin coğrafi/mülki sınırlarına taşınması bölgesel yönetim tartışmalarını da beraberinde getirecektir.
Mehmet GÜRBÜZ*

Uğur YILDIRIM**

Aziz BELLI***

Yrd. Doç. Dr.

Kahramanmaraş Sütçü İmam Üniversitesi

Coğrafya Bölümü

*Prof. Dr.

Kahramanmaraş Sütçü İmam Üniversitesi

Kamu Yönetimi Bölümü

**Arş. Gör.

Kahramanmaraş Sütçü Imam Üniversitesi

Kamu Yönetimi Bölümü 


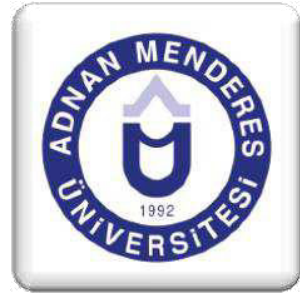

\section{Metropolitan Municipality Analysis on Scale of Kahramanmaraş}

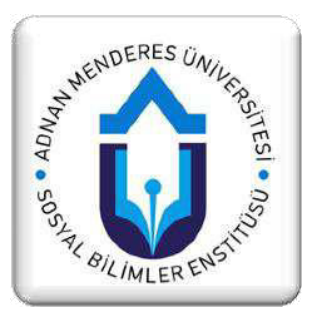

\section{Abstract}

Growing expectations of public from municipalities and growing cities as in population and geopraphical create a need in new regulation in Municipaility Law in Turkey. Because of this, in 1982, a new law was effective which is constant of bringing new management organization in large population areas. Based upon this law, first metropolitan municipality was established in 1984. After that there has been some regulation, at last, Metropolitan municipality Law numbered as 6360 has been effective in 2012. Kahramanmaraş has become Metropolitan Municipality after elections in 2014, There have been some changes with becoming metropolitan municipality such as; Municipality border was combined with city borders., Town municipalites were closed, administrative statues of town, district, village were cancelled and they converted to neighborhood which has no legal entity. Before accepting Metropolitan Municipalites, municipalities which are giving services to town and cities are started to give sercies to rural settlements too. This changement made concept of management understanding and it become from central (city) management to area management.

Defining borders of Metropolitan Municipality of Kahramanmaraş as city borders and closing town municipalites are positive improvement in term of economics scale. It also decrease cost of services and give services more effectively. However, there are some locations which are North of city and are seperated from city with high mountains. It is certain that cost of service will be higher in these locations and there will be important changes in duty, charge, responssabilities, contributions and representaion. It was not possible to continue giving servies in a profitable level in scope of distribution duty,charge and responsabilities because of these changes. Geopraphical growth, topographical diversity and spatial distance will effect quality and cost of services, delivering services in time needed. In the same time, our municipality legistation, services culture are not convenient in giving services in rural settlements. Because of this, there will be some problems in application of rural politics in rural settlements which are entered services area of municipality with Metropolitan Municipality Law. Moreover, some local managerial arguments will arise because of city borders changed from geopraphical and territorial borders with the changement of metropolictan city to big city arrangement, managerial transformation based upon duty, resource and scale increase understanding.

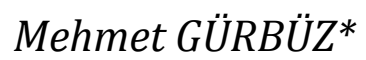

Uğur YILDIRIM**

Aziz BELLI'***

Yrd. Doç. Dr.

Kahramanmaraş Sütçü İmam Üniversitesi

Coğrafya Bölümü

*Prof. Dr.

Kahramanmaraş Sütçü Imam Üniversitesi

Kamu Yönetimi Bölümü

**Arş. Gör.

Kahramanmaraş Sütçü İmam Üniversitesi

Kamu Yönetimi Bölümü

Keywords: Metropolitan Municipality Law, Kahramanmaraş, Changes. 


\section{GíRiş}

Bir yerel yönetim birimi olan belediye teşkilatının Türkiye'de kuruluşu Osmanlı İmparatorluğu'na kadar uzanmaktadır. İlk olarak 1854 yılında İstanbul'un belirli bölgesinde kurulan belediye teşkilatı (Erkul, 2010: 39), 1868 yılında İstanbul'un geneline yayılmıştır. İl ölçeğinde ilk yerel yönetim denemesi ise 1864 yılında gerçekleşmiştir (Arıkboğa, 2007a). Cumhuriyetin ilanından sonra 1930 yılında çıkarılan 1580 sayılı Belediye Kanunu ise uzun süre yürürlükte kalmıştır. Çok partili hayata geçişle birlikte 1950'den sonra hızlanan iç göçler nedeniyle belediye teşkilatı bulunan yerleşmeler, nüfus ve mekânsal alan olarak hızla büyümeye başlamıştır. Bu hızlı büyümenin yaşandığı şehirlerdeki belediyeler görevlerini yerine getirmede bir takım sorunlarla karşı karşıya kalmışlardır. Bu sorunları aşmak için belediye teşkilatında yeni düzenlemeler yapma ihtiyacı ortaya çıkmıştır. Bu ihtiyaca binaen 1982 Anayasasının 127. maddesinin 3. fikrasında, büyük yerleşim yerleri için özel yönetim birimleri geliştirilebilir hükmü getirilmiştir. Anayasanın bu maddesine dayanılarak Türkiye'deki ilk büyükş̧ehir belediyesi 1984 yılı Ocak ayında çıkarılan 2972 sayılı kanun ve Mart ayında çıkarılan 195 sayılı Kanun Hükmünde Kararname (KHK) ile üç büyük şehirde (İstanbul, Ankara, İzmir) kurulmuş ve bu Kanun Hükmünde Kararname daha sonra 3030 sayılı Büyükşehir Belediye Kanunu ile değiştirilmiştir (İzci ve Turan, 2013).

3030 sayılı Kanun'un 2004 yılında 5216 sayı1ı Kanun ile yürürlükten kaldırılması ile büyükşehir kanununda önemli değişiklikler olmuştur. 2004 yılında çıkarılan 5216 sayılı Büyükşehir Belediyesi Kanunu'na göre, bir yerde büyükşehir belediyesi kurulabilmesi için belediye sınırları ve bu sınırlara en fazla $10.000 \mathrm{~m}$ uzaklıktaki yerleşim birimlerinin son nüfus sayımına göre toplam nüfusunun 750.000 'den fazla olan il belediyeleri, fiziki yerleşim durumları ve ekonomik gelişmişlik düzeyleri de dikkate alınarak, kanunla büyükşsehir belediyesine dönüştürülebilmektedir. Bu kanuna göre, Büyükşehir belediyelerinin sınırları adını aldıkları büyükşehirlerin belediye sınırları, büyükşehir ilçe belediyelerinin sınırları ve bu ilçelerin büyükşehir belediyesi içinde kalan kısımlarının sınırları olarak belirlenmiştir. Aynı kanun nüfus yoğunluğu çok yüksek olan İstanbul ve Kocaeli (İzmit) illerinin tamamını büyükşsehir sınırları içerisine almaktadır. Diğer büyükşehirlerin sınırları için coğrafi ölçüm şartı getirilmiştir. Buna göre, il sınırları içinde olmak ve valilik binası merkeze alınmak suretiyle; nüfusu 2.000.000'dan fazla olan büyükşehirlerde $50 \mathrm{~km}$ yarıçapı içerisindeki yerleşim yerleri, nüfusu $1.000 .000-2.000 .000$ arası olan büyükşsehirlerde $30 \mathrm{~km}$ yarıçap1 içerisindeki yerleşim yerleri, nüfusu 1.000 .000 'dan az olan büyükşsehirlerde ise $20 \mathrm{~km}$ yarıçapı içerisindeki yerleşim yerleri büyükşehir belediyesine dâhil edilmiştir.

2012 y1lında, 5216 sayılı Kanun'da büyükșehir belediyesinin kuruluşunu düzenleyen 4. maddesi, 6360 Sayı1ı On Üç İlde Büyükşehir Belediyesi ve Yirmi Altı İlçe Kurulması ile Bazı Kanun ve Kanun Hükmünde Kararnamelerde Değişiklik Yapılmasına Dair Düzenleme ile değiştirilmiştir. Buna göre, büyükşehir belediyesi kurulacak bir yerin il merkezi olması ve toplam nüfusunun 750.000'den fazla olmas1 gerekmektedir. Aynı zamanda büyükşsehir belediye sınırı, o ilin mülki idare sınırı olarak belirlenmiştir. Büyükşehir belediyesi sınırları içine katılan ilçe belediyeleri ile nüfusu 20.000 ve üzerinde olan belediyeler büyükşsehir ilçe belediyesine dönüştürülmüştür. Bu kanunun gerekçesinde hizmet sunumu bakımından daha etkili ve verimli bir yönetsel yapının inşa edileceği ve bu yapının demokratik hayata katılımı sağlayacağı da ifade edilmiştir. Büyükşehir Belediye Kanunu ile birlikte idari yapıda, mali sistemde, siyasal coğrafyada, temsil ve katılımda, personel yapısı, hizmet sunumu ile imar ve planlama düzeninde önemli değişiklikler olmuştur (İzci ve Turan, 2013). Bu kanunda, büyükşehir yapılan iller için tüm il sınırlarının büyükşehir belediye sınırı olarak kabul edilmesi, köylerin ve belde belediyelerinin kapatılarak mahalle statüsüne dönüştürülmesi, il özel idarelerinin kapatılarak belediyelere devredilmesine ilişkin hükümler de yer almaktadır. Bu kanunla belediye sınırlarının mülki idare sınırları ile örtüştürülmesi teorik olarak kırsal nüfusu ortadan kaldırmıştır. Bu değişiklikler belediye yönetim anlayışında bir ezberi bozmuş ve merkez (şehir) yönetiminden mekânsal alan yönetimine doğru bir geçiş yaşanmıştır (Gürbüz, 2013: 2). Kanunda yönetsel olarak tüzel kişiliklerin kaldırılması, yeni tüzel kişilik ihdas edilmesi, idari bağlılık ve isim değişikliği, birleşme ve katılmalar, sınır değişiklikleri ve yetki bölüşümü gibi değişiklikler de vardır. Siyasi sınırların veya seçim çevrelerinin değiştirilmesi ile birlikte, temsil ve katılım sürecinde değişiklikler olmuştur. Mülki sınırlar ile belediye sınırlarının örtüştürülmesi sonucunda belediye hizmet alanının genişlemesi imar ve planlama hizmetleri başta olmak üzere belediyelerinin hizmet sunumuna ilişkin 
değişikliklere de yol açmaktadır. Bu yeniden yapılanma süreci yerel yönetimlerin görev, yetki ve hizmet alanlarını değiştirmekte, hizmet üretilen mekânsal yapının yeniden belirlenmesi ile birlikte bu hizmeti sunan kuruluşların yapısı da buna göre yeniden düzenlenmektedir (İzci ve Turan, 2013). K1saca bu kanunla büyükşsehir belediyesinin kuruluşu, sınırları ve bütçesi konularında reform niteliğinde değişiklikler yapılmış olup, yerel yönetim sistemimize yeni bir anlayış kazandırılmıştır.

Bu çalışmanın amac1, 6360 sayılı kanunda yer alan ve 30 Mart 2014 yerel seçimi ile uygulamaya konulan, büyükşehir belediyelerinde meydana gelen idari ve mali sistemdeki değişiklikleri Kahramanmaraş ili ölçeğinde analiz etmektir.

\section{MATERYAL ve METOT}

$\mathrm{Bu}$ çalışmada, belediye teşkilatı ile ilgili kanunlar incelenmiş ve bu kanunlardaki belediye kurulma kriterleri dikkate alınmıştır. Kahramanmaraş ilinin köy, belde, ilçe merkezi ve il merkezine ait sosyoekonomik ve demografik veriler Türkiye İstatistik Kurumu (TÜİK) ve Kalkınma Bakanlığı'ndan, ilçe ve beldeler arası uzaklıklar ise Google Maps kullanılarak elde edilmiştir. Aynı zamanda Kahramanmaraş ilinin coğrafi ve sosyo-ekonomik özellikleri belirlenmiştir. Çalışmada kullanılmak üzere elde edilen bu verilerin tasnifi yapılmıştır. Bu veriler ışığında Büyükş̧ehir Belediye Kanunu ile idari ve mali sistemde meydana gelen değişiklikler Kahramanmaraş ili ölçeğinde analiz edilmiştir. Bu çalışmada kullanılan ve analizler sonucu elde edilen veriler ArcGIS yazılım programı ile haritalanmış ve mekânsal değerlendirilmesi yapılmıştır.

\section{KAHRAMANMARAȘ İLININ COĞRAFİ ÖZELLIIKLERİ ve SOSYO-EKONOMIKK YAPISI}

Kahramanmaraş ili, Akdeniz Bölgesi'nin Adana Bölümü’nde yer almaktadır. Kahramanmaraş, kuzeyden Sivas, kuzeydoğudan Malatya, doğudan Adıyaman, güneyden Gaziantep, batıdan Adana ve Osmaniye, kuzeybatıdan Kayseri illeri ile çevrilidir (Şekil 2). Kahramanmaraş, $14.457 \mathrm{~km}^{2}$ yüzölçümü ile alan büyüklügü bakımından Türkiye'nin 12. ili konumundadır.

Kahramanmaraş il sınırlarında yükselti 350 metreden başlayıp 3090 metreye kadar çıkmaktadır. Yeryüzü şekilleri büyük ölçüde Güneydoğu Torosların uzantıları olan dağlar ile bu dağlar arasında kalan çöküntü alanlarından oluşmaktadır. Ovalar çoğunlukla Ceyhan Vadisi etrafında yer alır. Dağlık alanlarla ovalar arasında ise platolar yer alır. Kahramanmaraş İli arazisinin \%59,7'sini dağlar, \%24'ünü platolar ve \%16,3'ünü de ovalar oluşturmaktadır (Kahramanmaraş Çevre ve Şehircilik İl Müdürlüğü, 2011:4).

Kahramanmaraş İli, Akdeniz Bölgesi'nin Doğu Akdeniz Bölümü’nde yer almakla birlikte konum itibarı ile Akdeniz Bölgesi'nin İç Anadolu, Güneydoğu Anadolu ve Doğu Anadolu bölgelerine geçiş alanında bulunmaktadır. Bu nedenle Kahramanmaraş ilinde genel olarak bozulmuş Akdeniz iklimi hâkimdir (Korkmaz, 2001: 16). Kahramanmaraş ilinde iklim ve yeryüzü şekillerinde görülen çeşitlilik zengin su kaynaklarının oluşmasına neden olmuştur.

Kahramanmaraş İlinin toplam yüzölçümü 1.445 .700 ha olup, orman ve fundalık alanlar 512079 ha ile il yüzölçümün \% 36'sını, çayır ve mera alanı 184514 hektar ile \%13'ünü, tarım alanları 352426 hektar ile \% 24'ünü oluşturmaktadır. 


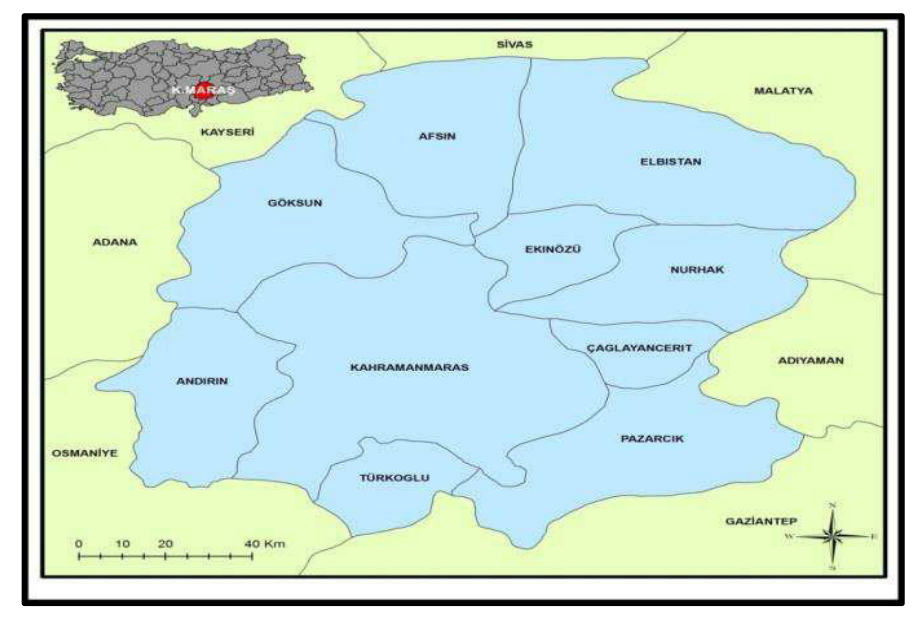

Şekil 1. Kahramanmaraş İli Lokasyon Haritası

Kahramanmaraş ve çevresinde iklimin insan yaşamına uygunluğu, verimli ovaların varlığı, su kaynaklarının bolluğundan dolayı yerleşimin Paleotik Çă̆'dan itibaren başladığı ve günümüze kadar devam ettiği anlaşılmaktadır. Kahramanmaraş'ın Döngel Mahallesindeki Direkli Mağarası'nda yapılan çalışmalarda yerleşme tarihinin Paleolitik Çağ olan MÖ 10730 yıllarına kadar indiği tespit edilmiştir (Eker, 2013). Kahramanmaraş şehrinin ise kale çevresinde Hititler tarafindan (MÖ XIX.-XII. yy) kurulduğu tahmin edilmektedir (Gürbüz vd., 2004).

Kahramanmaraş, $14.457 \mathrm{~km}^{2}$ yüzölçümü ile alan büyüklüğü bakımından Türkiye'nin 12., 1.075.706 nüfusu ile nüfus bakımından 18. ili konumundadır. Cumhuriyetin ilanından sonra ilk nüfus sayımı 1927 yılında yapılmıştır. Bu sayımda 184.958 kişi olan Kahramanmaraş İlinin nüfusu 2000 yılında 1 milyonu aşmış ve 2013 yılında 1.075.706 kişi olmuştur (Şekil 2). Kahramanmaraş İli şehir nüfusu 1927 yılında 36.343 iken bu tarihten itibaren sürekli artarak 2012 yılında 675.589 kişi olmuş ve şehir nüfus oranı \%66'ya çıkmıştır. Büyükşehir Belediye Kanunu ile Kahramanmaraş ilinin tüm nüfusu şehir nüfusu statüsüne girmiştir.

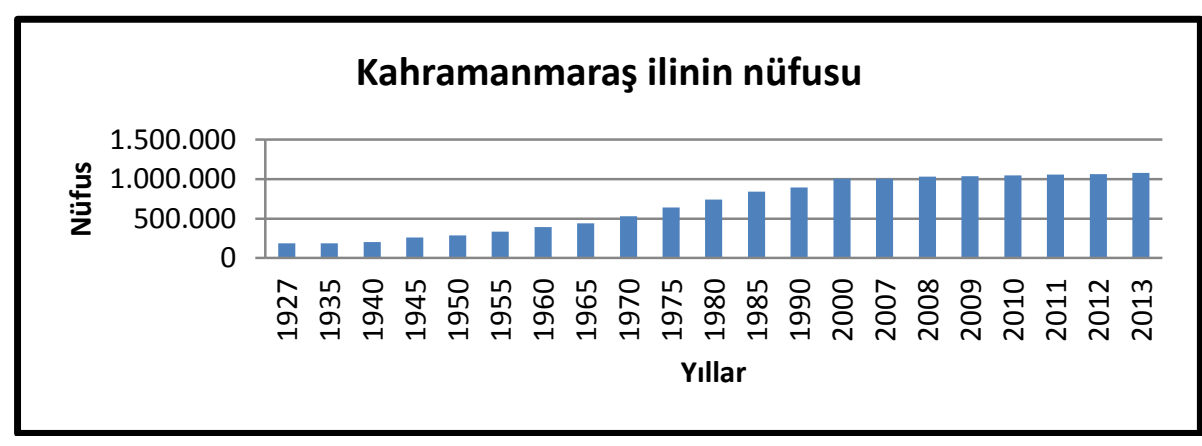

Şekil 2. Kahramanmaraş İl Nüfusunun Yıllara Göre Değişimi

Türkiye İstatistik Kurumu'nun 2000 y1lı verilerine göre, Kahramanmaraş ilinde 12+ yaşta toplam 715.730 kişi vardır. Bu nüfusun 412.000 kişisi (\%58) işgücünde, 303.730’u (\%42) işgücünde olmayanlardan oluşmaktadır. İşü̈cünde olanların 379.730’u (\%92) çalışmakta, 32.270’i (\%8) işsiz konumdadır.

Kahramanmaraş ilinde nüfusun esas mesleklere göre dağılımı incelendiğinde, \%36'sının mesleğinin olmadığı görülmektedir. Tarım ve hayvancılıkta çalışanlar \%38 ile en yüksek orana sahiptir. Bunu \%16 ile tarım dışı üretim faaliyetlerinde çalışanlar ve ulaştırma makineleri kullananlar, \%4 ile ilmi ve teknik elemanlar ve serbest meslek, \%3 ile hizmet işlerinde çalışanlar takip etmektedir (Şekil 3). 


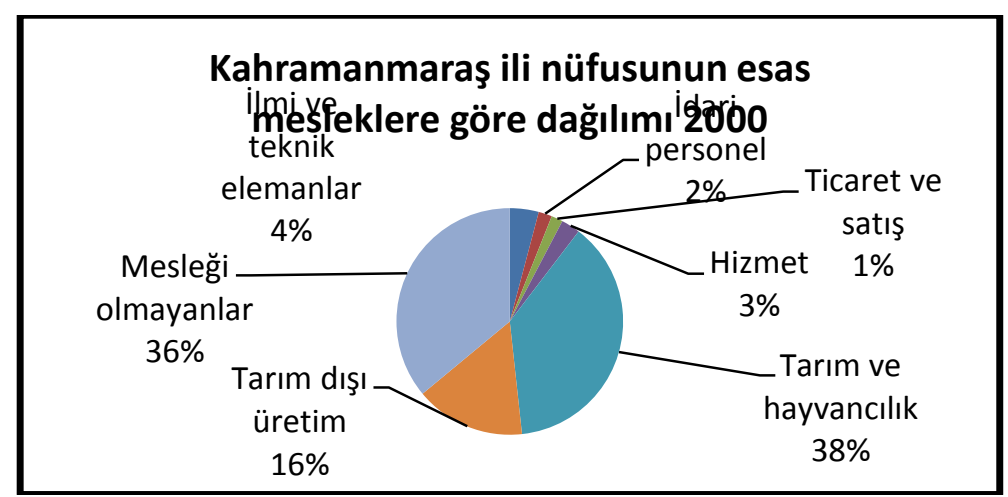

Şekil 3. Kahramanmaraş İli Nüfusunun Mesleklere Göre Dağılış Grafiği

Kahramanmaraş ilinde istihdam edilen nüfusun \%66'sı tarım, \%12'si toplum hizmetleri, \%8'i imalat sanayinde, \%5'i toptan ve perakende de, \%4'ü inşaatta, \%2'si ulaşım ve haberleşme de, \%1'i elektrik, su, gaz, \%1'i mali kurumlarda çalışmaktadır (Tablo 1).

Tablo1. Kahramanmaraş İlinde Ekonomik Faaliyete Göre İstihdam Edilen Nüfus 2000 (12+ yaş)

\begin{tabular}{|l|r|r|}
\hline Ekonomik Faaliyetler & İstihdam & $\%$ \\
\hline Tarım & 249204 & 66 \\
\hline Madencilik & 835 & 0 \\
\hline İmalat sanayi & 31880 & 8 \\
\hline Elektrik, gaz, su & 4656 & 1 \\
\hline İşaat & 15440 & 4 \\
\hline Toptan ve perakende ticaret & 20323 & 5 \\
\hline Ulaşım ve haberleşme & 6656 & 2 \\
\hline Mali kurumlar & 4047 & 1 \\
\hline Toplum hizmetleri & 46412 & 12 \\
\hline İyi tanımlanmamıs faaliyetler & 277 & 0 \\
\hline Toplam & 379730 & 100 \\
\hline
\end{tabular}

Kaynak: TÜİK

Kahramanmaraş'ta sanayinin sektörel analizine bakıldığında; dokuma, iplik, hazır giyim, çelik mutfak eşyaları ve gıda sektörü bazında işletme ve işçi sayısının ağırlıklı olduğu görülmektedir (Tablo 2). Ancak sektörlerin analizinde dikkati çeken bir diğer nokta, bilgi teknolojilerine ilişkin sektörlerin Kahramanmaraş'ta gelişmediği ve bu anlamda yatırıma ihtiyacı olduğudur.

Tablo 2. Kahramanmaraş’ta Sektör Bazında İşyeri ve İşçi Sayıları

\begin{tabular}{|c|c|c|c|c|}
\hline Sektörler & $\begin{array}{l}\text { İşyeri } \\
\text { Sayısı } \\
\end{array}$ & $\begin{array}{c}\text { Çalışan Sayısı } \\
\text { (Erkek) }\end{array}$ & Çalışan Sayısı (Kadın) & Toplam \\
\hline Dokuma & 30 & 3.749 & 388 & 4.137 \\
\hline İplik & 76 & 17.860 & 1.652 & 19.512 \\
\hline Konfeksiyon & 74 & 3.902 & 1.715 & 5.617 \\
\hline Örme & 53 & 5.033 & 410 & 5.443 \\
\hline Boya-Kasar & 31 & 5.490 & 549 & 6.039 \\
\hline Denim & 3 & 1.425 & 221 & 1.646 \\
\hline
\end{tabular}




\begin{tabular}{|l|r|r|r|r|}
\hline Hidrofil Pamuk & 1 & 15 & 10 & 25 \\
\hline Çırçır & 32 & 397 & 74 & 471 \\
\hline Gıda & 163 & 1.870 & 590 & 2.460 \\
\hline Süt ve Süt Ürünleri & 28 & 654 & 423 & 1.077 \\
\hline Tarımsal İmalat & 28 & 234 & 27 & 261 \\
\hline Yem & 10 & 214 & 39 & 253 \\
\hline Yapı-Sanayi & 105 & 1.770 & 99 & 1.869 \\
\hline Kereste ve Plastik & 35 & 337 & 13 & 350 \\
\hline Çelik Mutfak & 77 & 2.632 & 479 & 3.111 \\
\hline Eşyaları & 18 & 714 & 100 & 814 \\
\hline Ambalaj & 105 & 5.783 & 587 & 6.370 \\
\hline Diğer & 869 & 52.079 & 7.376 & 59.455 \\
\hline Toplam & & & & \\
\hline
\end{tabular}

Kaynak: Kahramanmaraş Ticaret ve Sanayi Odası, http://www.kmtso.org.tr, E.T. 08.03.2014

Devlet Planlama Teşkilatı (DPT) tarafindan 2003 yılında yaptırılan bir çalışmaya göre; Kahramanmaraş ili sosyo-ekonomik gelişmişlik sıralamasında -0,34968 endeks değeri ile iller içerisinde 48. sırada, imalat sanayi gelişmişlik sıralamasında $-0,02970$ endeksi ile 27 . sırada, sağlık sektörü gelişmişlik sıralamasında $-0,48975$ endeksi ile 59. sırada, eğitim sektörü gelişmişlik sıralamasında ise $-0,27060$ endeksi ile 54. sırada yer almaktadır (Dinçer v.d., 2003:55, 118,123,129). Kahramanmaraş ilinin 2010 yılı gelişmişlik sıralaması 38 , genel ekonomi sıralaması 23 , kişi başı ekonomi sıralaması 30 , işgücü sıralaması 30 , sosyal gelişmişlik sıralaması 62'dir (Eraydın vd., 2012).

Kahramanmaraş ili 2009-2010 yılı Uluslararası Rekabet Araştırmalar Kurumu (URAK) iller arası rekabetçilik genel endeks sıralamasında 18,82 endeks değeri ile 34. sırada, iller arası rekabetçilik beşeri sermaye ve yaşam kalitesi alt endeksi sıralamasında 56. sırada, iller arası rekabetçilik markalaşma becerisi ve yenilikçilik alt endeksi sıralamasında 21. sırada, iller arası rekabetçilik ticaret becerisi ve üretim potansiyeli alt endeksi sıralamasında 18. sırada ve iller arası rekabetçilik erişilebilirlik alt endeksi sıralamasında 31. siradadır (URAK, http://www.urak.org, 04.03.2014).

Kalkınma Bakanlığı'nın 2011 yılında yaptığı “ïllerin ve Bölgelerin Sosyo-Ekonomik Gelişmişlik Sıralaması Araştırması'na (SEGE) göre Kahramanmaraş, 60. sırada yer almaktadır. 2012 yılı kişi başına milli gelir sıralamasında 10681 \$ ile 81 il arasından 52. sırada olup kişi başına milli gelir bakımından Türkiye ortalamasının (15137 \$) altındadır.

$\mathrm{Bu}$ veriler incelendiğinde; Kahramanmaraş, genel ekonomik gelişmeler bakımından iyi konumda olmasına rağmen, sosyo-ekonomik gelişmişlik bakımından geri durumda olduğu ve var olan ekonomik potansiyelini kullanamadığı görülmektedir (Gürbüz, 2013: 23). Kahramanmaraş'ın sosyo-ekonomik ve kültürel anlamda gelişmişliği yakalamak için büyükşehir belediye sınırları içerisinde eğitim, sağlık, sosyal hizmetler ve sosyal güvenlik gibi alanlarda büyük proje ve yatırımlara ihtiyacı olduğu görülmektedir.

\section{BÜYÜKŞEHIIR BELEDIYE KANUNU'NUN KAHRAMANMARAŞ'TA MEYDANA GETİRDİĞİ DEĞIŞIKLIIKLER}

6360 sayılı On Üç İlde Büyükşehir Belediyesi ve Yirmi Altı İlçe Kurulması ile Bazı Kanun ve Kanun Hükmünde Kararnamelerde Değişiklik Yapılmasına Dair Kanun 6 Aralık 2012 tarihli 28489 sayılı resmi gazetede yayınlanmıştır. Genel gerekçesi iki temel üzerine inşa edilen kanun ile hizmet sunumu bakımından daha etkili ve verimli bir yönetsel yapının inşa edileceği ve bu yapının demokratik hayata katılımı sağlayacağı ifade edilmiştir (İzci ve Turan, 2013). Büyükşehir Kanunu'nun amacı; il sınırları içerisindeki belediye yönetimini, Anayasanın temel düzenlemeleri çerçevesinde yer alan yerinden yönetim ilkesine uygun olarak yapılandırmaktır. Ak Parti Genel Merkezi Yerel Yönetimler Başkanlığı (2012), Büyükşehir belediye sınırının il mülki sınırları ile birleştirilmesini şu şekilde açıklamaktadır: "Bu çerçevede 
yönetim, planlama ve koordinasyon açısından belediye sınırı mülki sınıra genişletildiğinde, en geniş ölçekte hizmet üretebilecek güçlü bir yapı sağlanacaktır. Büyükşehir alanında sunulan hizmetlerin tek merkezden yürütülmesiyle ortaya çıkan ölçek ekonomileri sayesinde hizmetlerde etkinlik, koordinasyon ve kalite yükselecek, daha az kaynakla daha çok ve daha kaliteli hizmet sunulması mümkün hale gelebilecektir. Bu doğrultuda kanunun kısaca amacı; çağdaş belediyecilik anlayışının gerekliliği olan en yüksek verimlilikle, hızlı ve kaliteli hizmet bütünlüğünün sağlanmasıdır. Ayrıca hizmetin en yakın yönetim birimi tarafından yerine getirilmesi ilkesi doğrultusunda yerel yönetimlere daha çok yetki aktarılarak özerkliklerinin arttırılmasını öngörmektedir. Bütün bunlar göz önünde bulundurulduğunda denilebilir ki, bu düzenlemenin amacı; hizmet siyasetinin, dolayısıyla çağdaş belediyecilik anlayışının gerekliliği olan en yüksek verimlilikle, hızlı ve kaliteli hizmet bütünlüğünün sağlanmasıdır" (Ak Parti Genel Merkezi Yerel Yönetimler Başkanlığı, 2012: 9).

6360 sayılı Kanuna göre Aydın, Balıkesir, Denizli, Hatay, Malatya, Manisa, Kahramanmaraş, Mardin, Muğla, Tekirdağ, Trabzon, Şanlıurfa ve Van illerinde, sınırları il mülki sınırları olmak üzere aynı adla büyükşehir belediyesi kurulmuş ve bu illerin il belediyeleri büyükşsehir belediyesine dönüştürülmüştür. 2013 yılında 6447 sayı1ı Kanun ile Ordu ili de büyükşehir olmuştur (Tablo 3).

Tablo 3. Büyükșehir Belediyeleri ve Kuruluș Yılları

\begin{tabular}{|c|c|c|c|c|c|c|c|}
\hline Belediye & Nüfus (2012) & Kuruluș Yılı & Dayanak & & & & \\
\hline & & & & $20 \mathrm{~km}$ & $30 \mathrm{~km}$ & $50 \mathrm{~km}$ & İl Sınırı \\
\hline Ankara & 4.630 .735 & 1984 & 3030 sayılı Kanun & & & $*$ & \\
\hline İstanbul & 13.710 .512 & 1984 & 3030 sayılı Kanun & & & & $*$ \\
\hline İzmir & 3.401 .994 & 1984 & 3030 sayılı Kanun & & & $*$ & \\
\hline Adana & 1.636 .229 & 1986 & 3306 sayılı Kanun & & * & & \\
\hline Bursa & 1.983 .880 & 1987 & 3391 sayılı Kanun & & $*$ & & \\
\hline Gaziantep & 1.438 .373 & 1987 & 3398 sayılı Kanun & $*$ & & & \\
\hline Konya & 1.107 .886 & 1987 & 3399 sayılı Kanun & $*$ & & & \\
\hline Kayseri & 1.004 .276 & 1988 & 3508 sayılı Kanun & $*$ & & & \\
\hline Antalya & 1.073 .794 & 1993 & 504 sayılı KHK & $*$ & & & \\
\hline Diyarbakır & 892.713 & 1993 & 504 sayılı KHK & $*$ & & & \\
\hline Erzurum & 384.399 & 1993 & 504 sayılı KHK & $*$ & & & \\
\hline Eskişehir & 659.924 & 1993 & 504 sayılı KHK & $*$ & & & \\
\hline Kocaeli & 1.527.407 & 1993 & 504 sayılı KHK & & & & * \\
\hline Mersin & 876.958 & 1993 & 504 sayılı KHK & $*$ & & & \\
\hline Samsun & 547.778 & 1993 & 504 sayılı KHK & $*$ & & & \\
\hline Sakarya & 590.498 & 2000 & 593 sayılı KHK & $*$ & & & \\
\hline Aydın & 1.006 .541 & 2012 & 6360 sayılı Kanun & & & & $*$ \\
\hline Balıkesir & 1.160 .731 & 2012 & 6360 sayılı Kanun & & & & $*$ \\
\hline Denizli & 950.557 & 2012 & 6360 sayılı Kanun & & & & $*$ \\
\hline
\end{tabular}




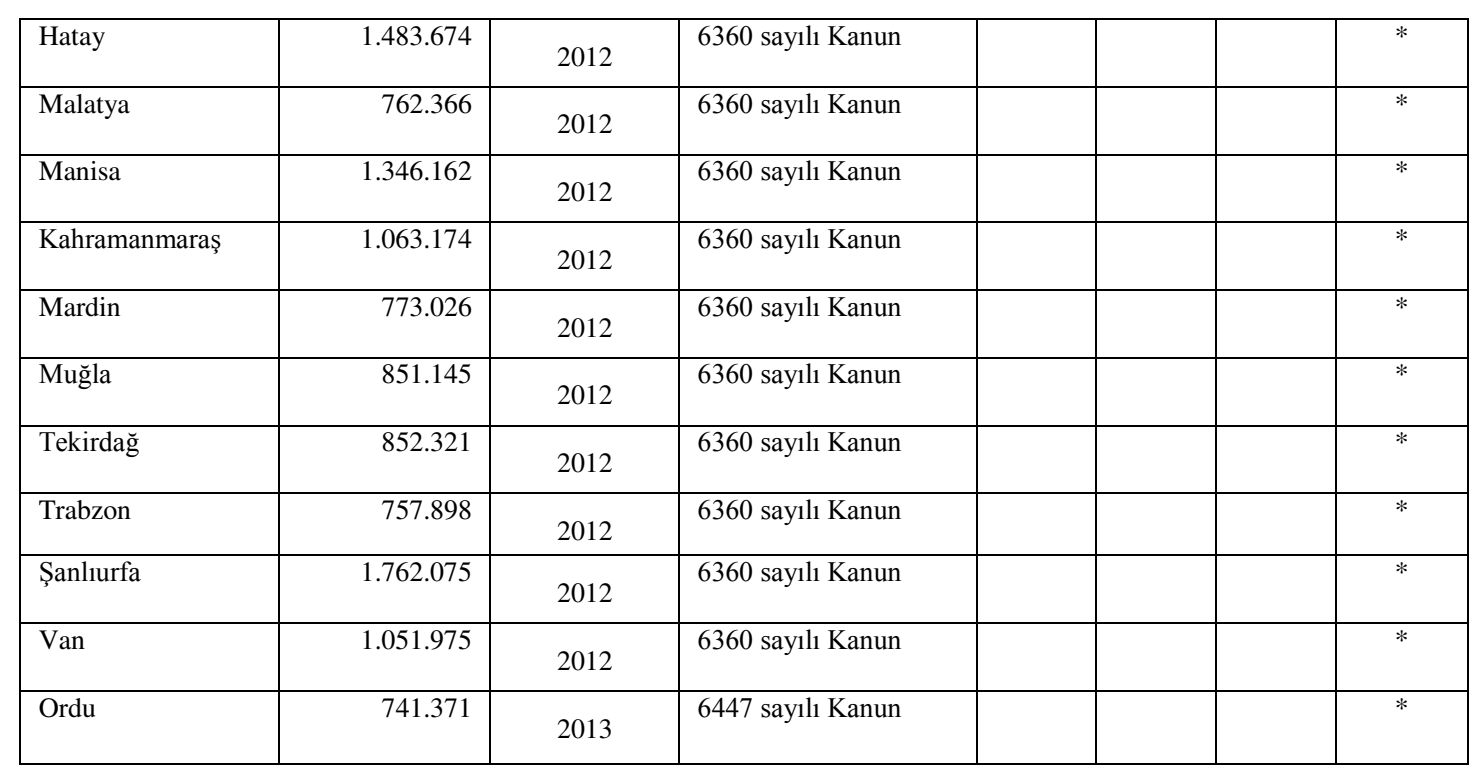

Not: 6360 sayılı Kanun ile Büyükşsehir belediye sınırı il mülki sınırları ile birleştirilmiştir.

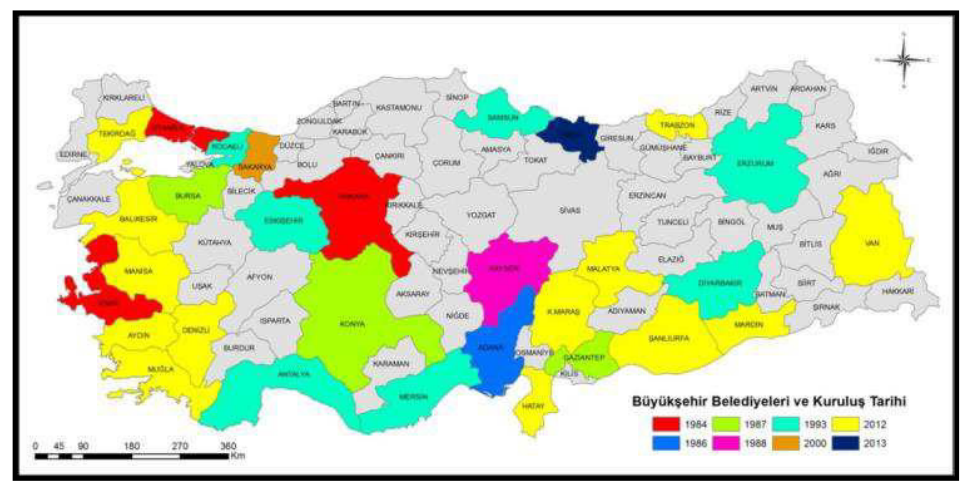

Şekil 4.Türkiye'de Kuruluş Yıllarına Göre Büyükşehir Belediyeleri Haritası(Gürbüz, 2013: 13)

$\mathrm{Bu}$ kanunla Kahramanmaraş, büyükşehir statüsü kazanmıştır. Kahramanmaraş Büyükşehir Belediyesi, arttırılan mali imkânlar ve devraldıkları İl Özel İdare varlıkları ile daha iyi imkânlara kavuşmuştur. İmkânların ve uzmanlığın birleştirilmesi ile hizmetin ilgili alanda uzman birimlerce görülmesi, hizmetin etkin ve verimli sunulmasında olumlu rol oynayacaktır. Büyükşehir Kanunu ile imar planlama ve uygulamaları Kahramanmaraş Büyükşehir Belediyesi tarafından hazırlanacak ve Kahramanmaraş ili ölçeğinde imar bütünlüğü büyük ölçüde sağlanacaktır.

\section{1. İDARİ SISTEMDE MEYDANA GELEN DEĞİŞİKLIKKLER}

Büyükşehir Kanunu ile Kahramanmaraş’ta meydana gelen önemli idari değişikliklerden biri yeni ilçelerin kurulmasıdır. Kahramanmaraş'ın Büyükşehir olmadan önce merkez ilçe ile birlikte 10 ilçesi vardı. 6360 sayılı Kanun ile birlikte Merkez ilçe Onikişubat ve Dulkadiroğlu adıyla ikiye ayrılarak ilçe sayısı 11'e çıkarıldı. Bu idari değişikliğe bağlı olarak sınır değişiklikleri meydana geldi. Kahramanmaraş şehri güney kuzey doğrultusunda doğu-batı olarak ayrılmış (Şekil 5), bu hattın batısında kalan mahalleler ile bazı belde ve merkez ilçeye bağlı köyler birleştirilerek Onikişubat ilçesi ve belediyesi, doğusunda kalan mahalleler ile bazı belde ve merkez ilçeye bağlı köyler, Pazarcık ilçesinin 9 köyü birleştirilerek Durkadiroğlu ilçesi ve belediyesi kurulmuştur. Dulkadiroğlu ilçesine; Kahramanmaraş şehrinin 43 mahallesi, Merkez ilçeye bağlı bir belde belediyesi, 48 köy ve Pazarcık'a bağlı 9 köy, Onikişubat ilçesine; Kahramanmaraş şehrinin 47 mahallesi ve Merkez ilçeye bağl1 10 belde belediyesi ve 71 köy bağlanmıştır. (Tablo 4 ). Bu düzenleme ile Pazarcık ilçesinin Kelebişler, Bayramgazi ve Cennetpınarı Köyleri ise Türkoğlu İlçesine bağlanmıştır (6360 
sayılı Kanun Md. 2/17-19). Görüldüğü üzere 6360 sayılı Kanun, Kahramanmaraş İl ölçeğinde önemli idari sınır değişiklikleri meydana getirmiştir.

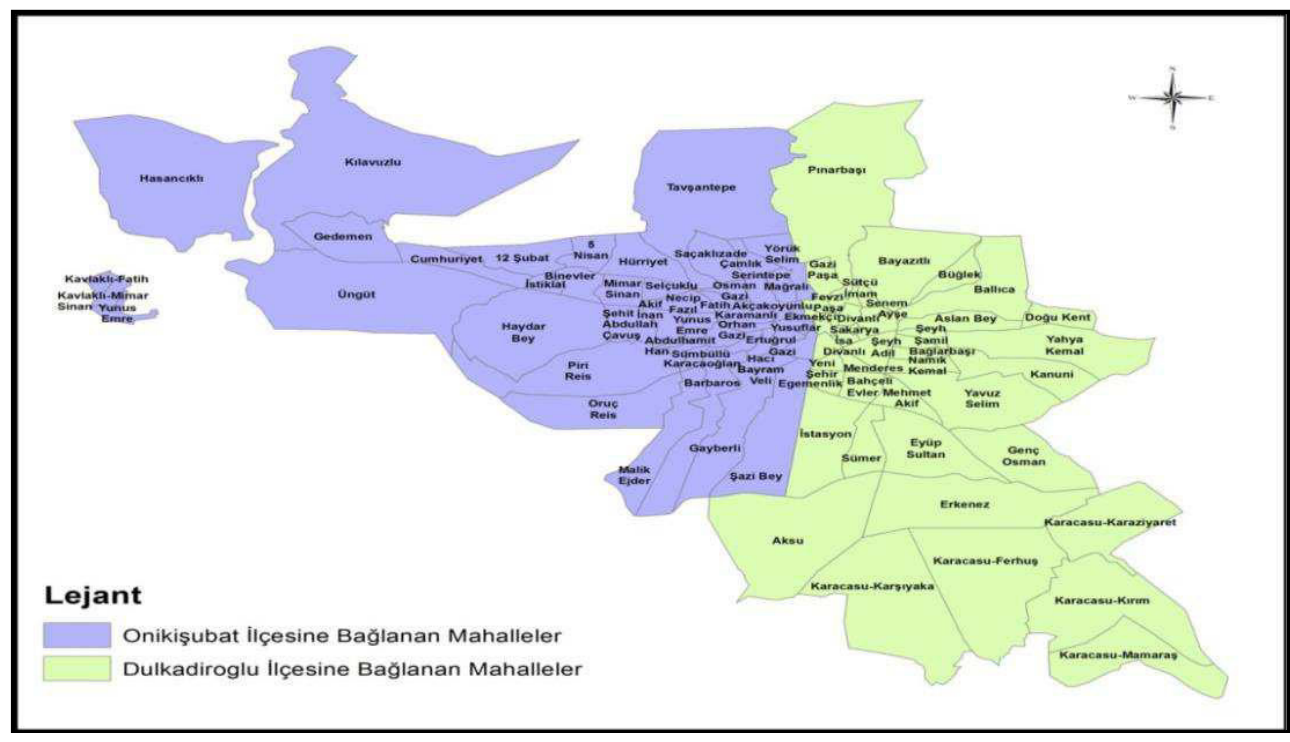

Şekil 5. Dulkadiroğlu ve Onikişubat İlçelerine Bağlanan Mahallelerin Haritası

Tablo 4. Onikişubat ve Dulkadiroğlu İlçesine Bağlanan Mahalle, Belde ve Köyler

\begin{tabular}{|c|c|c|c|c|}
\hline & \multicolumn{2}{|c|}{ Onikişubat İlçesi } & \multicolumn{2}{|c|}{ Dulkadiroğlu İlçesi } \\
\hline S.No. & Mahalleler & Belde ve Köyler & Mahalleler & Belde ve Köyler \\
\hline 1 & 12 Şubat & Karadere B. & Aksu & Baydemirli B. \\
\hline 2 & 5 Nisan & Kale B. & Aslan Bey & Abbaslar \\
\hline 3 & Abdülhamid Han & Fatmalı B. & Bağlarbaşı & Ağabeyli \\
\hline 4 & Akçakoyunlu & Fatih B. & Bahçeli Evler & Akyar \\
\hline 5 & Akif İnan & Önsen B. & Ballica & Alibeyuşağ \\
\hline 6 & Barbaros & Döngele B. & Bayazitlı & Ayaklicaoluk \\
\hline 7 & Bin Evler & Kürtül B. & Büğlek & Bahçeli \\
\hline 8 & Cumhuriyet & Şahinkayası B. & Divanl1 & Başdevrişli \\
\hline 9 & Çamlık & Ilica B. & Doğu Kent & Beşenli \\
\hline 10 & Dumlupınar & Tekir B. & Dulkadiroğlu & Boyalı \\
\hline 11 & Ertuğrul Gazi & Altınova & Durakl1 & Budakl1 \\
\hline 12 & Fatih & Ayşepınarı & Erkenez & Bulanık \\
\hline 13 & Gayberli & Avcilar & Eyüp Sultan & Çatmayayla \\
\hline 14 & Gedemen & Avşar & Genç Osman & Çiğli \\
\hline 15 & Hacı Bayram Veli & Beşen & Gazi Paşa & Çobanl1 \\
\hline 16 & Hasanciklı & Bulutoğlu & İsa Divanlı & Çokyaşar \\
\hline 17 & Haydar Bey & Büyüksır & İsmet Paşa & Dereköy \\
\hline 18 & Hayrullah & Cüceli & İstasyon & Dereli \\
\hline 19 & Hürriyet & Çağırgan & Kanuni & Ekberoğlu \\
\hline 20 & İstiklal & Çağlayan & Karacasu Ferhuş & Elmalar \\
\hline 21 & Karacaoğlan & Çakırdere & Karacasu Karaziyaret & Gaffarlı \\
\hline 22 & Karamanlı & Çakırlar & Karacasu Karşıyaka & Göllü \\
\hline
\end{tabular}




\begin{tabular}{|c|c|c|c|c|}
\hline 23 & Kavlaklı Fatih & Çamlıbel & Karacasu Kırım & Güzelyurt \\
\hline 24 & $\begin{array}{l}\text { Kavlaklı Mimar } \\
\text { Sinan }\end{array}$ & Çamlıca & Karacasu Mamaraş & Hacıeyüplü \\
\hline 25 & $\begin{array}{l}\text { Kavlaklı Yunus } \\
\text { Emre }\end{array}$ & Çevrepınar & Kayabaşı & Halkaçayırı \\
\hline 26 & Kılavuzlu & Çınarpınar & Kurtuluş & Kabasakal \\
\hline 27 & Mağralı & Çokran & Mehmet Akif & Kapıçam \\
\hline 28 & Malik Ejder & Çukurhisar & Menderes & Karamanlı \\
\hline 29 & Mevlana & Dadağl1 & Namık Kemal & Kartal \\
\hline 30 & Mimar Sinan & Demrek & Pınarbaşı & Kazanlıpınar \\
\hline 31 & Necip Fazıl & Dereboğazı & Sakarya & Kemalli \\
\hline 32 & Orhan Gazi & Döngel & Senem Ayşe & Kılağlı \\
\hline 33 & Oruç Reis & Gölpınar & Sümer & Kocalar \\
\hline 34 & Osman Gazi & Hacıağlar & Sütçü İmam & Kozludere \\
\hline 35 & Piri Reis & Hacibudak & Şeyh Adil & Kuzucak \\
\hline 36 & Selçuklu & Hacribrahimuşağ 1 & Şeyh Şamil & Küçüknacar \\
\hline 37 & Serintepe & Hacılar & Yahya Kemal & Küpelikız \\
\hline 38 & Sümbüllü & Hacımustafa & Yavuz Selim & Navruzlu \\
\hline 39 & Şazi Bey & Hacinınoğlu & Yeni Şehir & Osmanbey \\
\hline 40 & $\begin{array}{l}\text { Şehit Abdullah } \\
\text { Çavuş }\end{array}$ & Hartlap & Egemenlik & Öksüzlü \\
\hline 41 & Tavşan Tepe & İsmailli & Ekmekçi & Peynirdere \\
\hline 42 & Üngüt & Kalekaya & Fevzi Paşa & Sarıkaya \\
\hline 43 & Yunus Emre & Kapukaya & Turan & Sivricehüyük \\
\hline 44 & Yusuflar & Kaynar & & Şerefoğlu \\
\hline 45 & Yürükselim & Kerimli & & Tevekkelli \\
\hline 46 & Şehit Evliya & Kertmen & & Ulutaş \\
\hline 47 & Saçaklızade & Kısıklı & & Yenipınar \\
\hline 48 & & Kizıldamlar & & Yeniyurt \\
\hline 49 & & Kızılseki & & Yusufhacılı \\
\hline 50 & & Kozcağız & & Söğütlü \\
\hline 51 & & Kumarl & & Doğanlıkarahasan \\
\hline 52 & & Kurtlar & & Seyrantepe \\
\hline 53 & & Kurucaova & & Çınarlı \\
\hline 54 & & Küçüksır & & Denizli \\
\hline 55 & & Kümperli & & Eskinarlı \\
\hline 56 & & Köseli & & Maksutuşağ 1 \\
\hline 57 & & Maksutlu & & Arslanbey \\
\hline 58 & & Mimarsinan & & Demirciler \\
\hline 59 & & Muratli & & \\
\hline 60 & & Orhangazi & & \\
\hline 61 & & Öşlü & & \\
\hline 62 & & Öztürk & & \\
\hline
\end{tabular}




\begin{tabular}{|l|l|l|l|l|}
\hline 63 & & Payamlı & & \\
\hline 64 & & Rahmacılar & & \\
\hline 65 & Reyhanlı & & \\
\hline 66 & Sadılı & & \\
\hline 67 & Sarı̨ukur & & \\
\hline 68 & Sarıgüzel & & \\
\hline 69 & Sarımollalı & & \\
\hline 70 & Saygılı & & \\
\hline 71 & Selimiye & & \\
\hline 72 & Suçatı & & \\
\hline 73 & Suluyayla & & \\
\hline 74 & Süleymanlı & & \\
\hline 75 & Topçalı & & \\
\hline 76 & & Yaylaüstü & & \\
\hline 77 & & Yenidemi & & \\
\hline 78 & & Yeniköy & & \\
\hline 79 & & Yeniyapan & & \\
\hline 80 & & Yolyanı & & \\
\hline 81 & & Zeytindere & & \\
\hline
\end{tabular}

Kaynak: Gürbüz, 2013: 37-39

Kahramanmaraş İl Özel İdaresi kaldırılmış, 52 tane belde belediyesi kapatılmış ve statüleri mahalleye dönüştürülmüştür. Aynı zamanda 8 bucak merkezi (1'i belediye) ve 468 köy mahalleye dönüştürülmüsşür. Köy muhtarlıklarının mahalle muhtarlıklarına dönüştürülmesi ile Kahramanmaraş Büyükşehir belediyesinin 680 mahallesi olmuştur. Bu durumda tüzel kişiliğe sahip olan ve bir yerel yönetim türü olan belde belediyeleri ve köy muhtarlıkları, tüzel kişiliği olmayan ve yerel yönetim türleri arasında sayılmayan mahalle muhtarlıklarına dönüştürülmüştür. Aynı zamanda Mahalli İdare Birlikleri de kaldırılmıştır. Kahramanmaraş'ın bütün ilçeleri, coğrafi özellikleri, lokasyonu ve merkeze olan uzaklıkları göz önünde bulundurulmaksızın büyükşehir belediyesine bağlı ilçelere dönüşmüş ve il sınırları ile büyükşsehir belediyesi sınırları örtüşmüştür. Yani, tepede bir büyükşehir belediyesi ve ona bağlı büyükşehir ilçe belediyeleri gibi iki kademeli bir yapı kurulmuştur.

Kahramanmaraş il sınırı, coğrafi, sosyo-ekonomik ve kültürel özellikler bakımından bir bütünlük göstermemektedir. Kahramanmaraş ilinin tam ortasından Toros Dağlarının kolları geçmekte ve ili topografik olarak iki havzaya bölmektedir. Bu havzanın güneyinde; 1 il merkezi, 4 ilçe, 19 belde ve 257 köy yerleşmesi, kuzey havzasında ise; 5 ilçe, 33 belde ve 211 köy yerleşmesi bulunmaktadır (Şekil 5). Kahramanmaraş şehir merkezinde kurulu olan Büyükşehir belediyesi topografik olarak güney havzanın merkezinde yer alırken kuzey havzaya çok uzakta kalmaktadır. Bu uzaklık kuzeyde belediye hizmetlerinin birim maliyetini yükseltmektedir. Aynı zamanda seçmenler yerel yöneticiden uzaklaşmıştır. $\mathrm{Bu}$ sorunlar büyükşehir belediyesinin hizmet sunumunda çeşitli sorunlara neden olacak ve yurttaşların sunulan hizmetlerde eşit şekilde yararlanması mümkün olmayacaktır. Bunu sonucunda kuzey havzada yer alan yerleşmelerde yaşayan halk hizmetlerden yeterince yararlanamayacaktır.

Kahramanmaraş şehri merkez olmak üzere, $50 \mathrm{~km}$ yarıçapında bir zon belirlendiğinde güney havzasını içerisine almaktadır (Şekil 6). Kahramanmaraş'ın güney havzasındaki yerleşmelerin toplam nüfusu 759.611 kişi olup büyükşehir kriterlerini sağlamaktadır. Büyükşehir belediye sınırının bu havzayı kapsayacak şekilde olması Kahramanmaraş Büyükşsehir belediyesinin büyüklüğü ve bütünlüğü açısından daha uygulanabilir olduğu görülmektedir. 


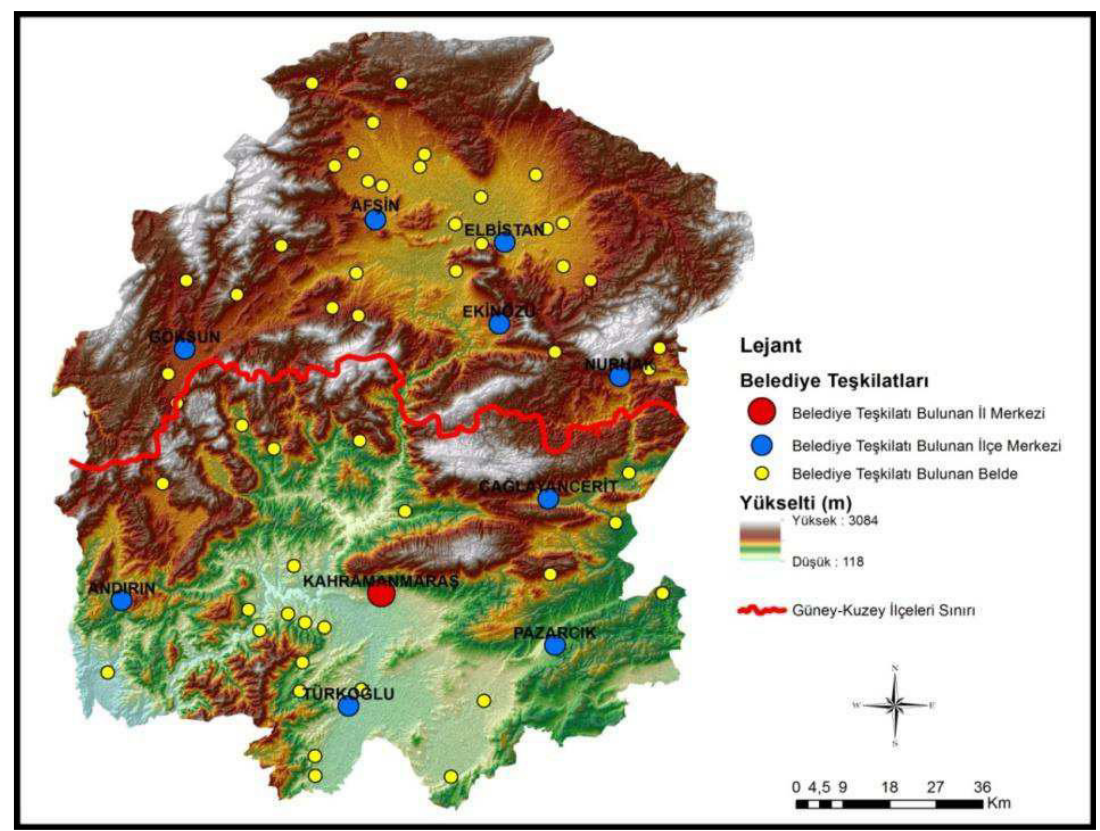

Şekil 6. Kahramanmaraş İli Güney-Kuzey İIçeleri Arasındaki İdari Sınır Haritası

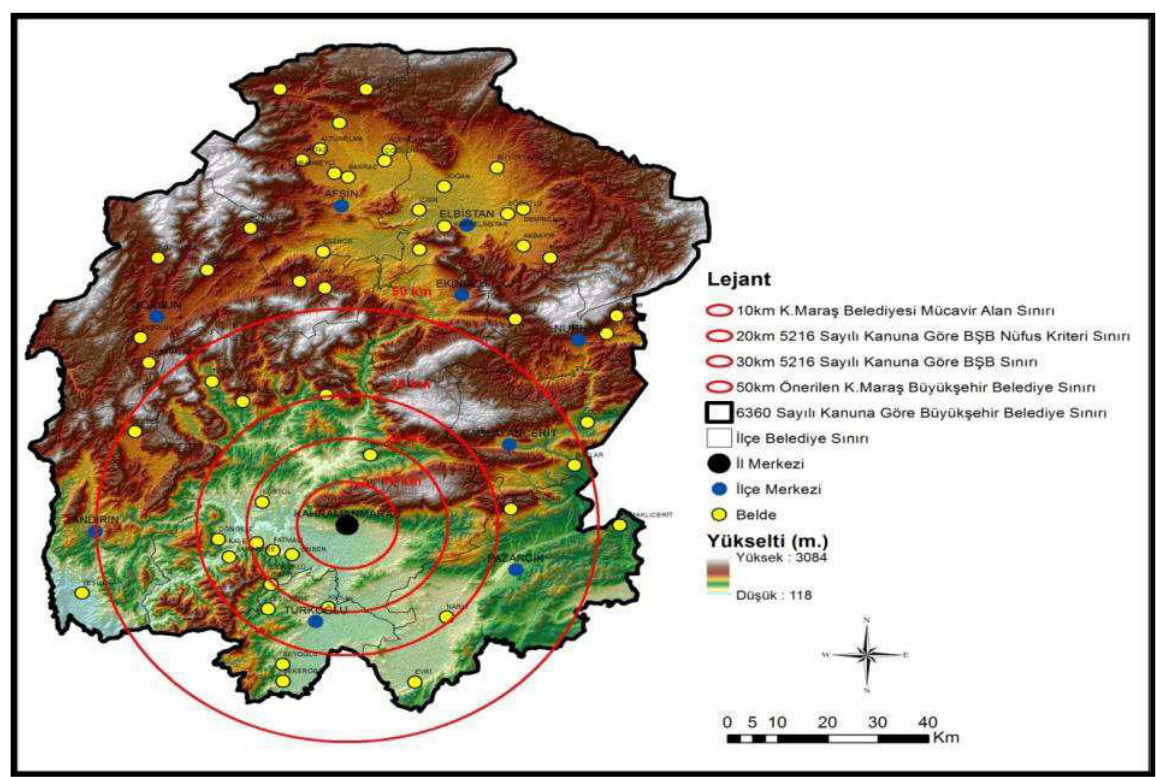

Şekil 7. Kriterlere Göre Kahramanmaraş Büyükşehir Belediye Sınırı Haritası

Kahramanmaraș Büyükșehir belediye sınırları içerisinde yukarıda bahsedilen idari sınır değişikliklerinin olması, belediye hizmetine tahsis edilen kaynaklar ile amaç arasındaki ilişkiyi belirleyen ve verimlilik kavramını da içeren fonksiyonel etkinlik ve halkın yönetime ilgisini gösteren demokratik katılım durumunu etkilemektedir. Bu iki temel özellik olan fonksiyonel etkinlik ve demokratik katılım mekân üzerinde ölçek kavramını ortaya çıkarmaktadır. Belediye hizmetlerinin niteliği, hizmetin hangi ölçekte uygulanmasının daha etkin olacağını belirlemektedir. Çoğu zaman fonksiyonel etkinlik ile demokratik katılım belediye sınırlarının ölçeği ile ters orantılı hareket etmektedir. Belediye sınırları büyüdüğünde hizmet bütünlüğü ve birim maliyetinin düşmesi sağlanırken, demokratik katılım azalmaktadır. Bu nedenle iki özelliğin uygun ölçekte çakıştığı ölçeği belirlemek çok önemlidir. Kahramanmaraş büyükşehir belediyesi olarak düşünüldüğünde, fonksiyonel etkinlik ve demokratik katılım açısından Kahramanmaraş valiliği 
merkez olmak üzere 50-60 km çapındaki bir zon içerisinde kalan Kahramanmaraş ili güney havzasının büyükşehir belediye sınırı olarak belirlenmesi daha uygun olacaktır.

\subsection{YATIRIM IZLEME ve KOORDINASYON BAŞKANLIĞI'NIN KURULMASI}

Büyükşehir Kanunu ile birlikte, büyükşehir illerinin tamamında kamu kurum ve kuruluşlarının yatırım ve hizmetlerinin etkin olarak yapılması, izlenmesi ve koordinasyonu, acil çağrı, afet ve acil yardım hizmetlerinin koordinasyonu ve yürütülmesi, ilin tanıtımı, gerektiğinde merkezi idarenin taşrada yapacağı yatırımların yapılması ve koordine edilmesi, temsil, tören, ödüllendirme ve protokol hizmetlerinin yürütülmesi, ildeki kamu kurum ve kuruluşlarına rehberlik edilmesi ve bunların denetlenmesini gerçekleştirmek üzere valiye bağlı olarak Yatırım İzleme ve Koordinasyon Başkanlığı kurulma kararı alınmıştır. Yatırım izleme ve koordinasyon başkanlıkları, afet yardım, acil çağrı, yatırım izleme, rehberlik ve denetim, strateji ve koordinasyon ile idari müdürlükler kurabilir. Gerektiğinde geçici birimler kurulabilir. Yatırım izleme ve koordinasyon başkanlıklarının çalışma usul ve esasları İçişleri Bakanlığı tarafından çıkarılacak yönetmelikle belirlenir (6360 sayılı Kanun Md. 34).

Yatırım izleme ve koordinasyon başkanlığının sevk ve idaresi, vali veya vali tarafindan görevlendirilecek bir vali yardımcısı tarafından yerine getirilir. Maliye Bakanlığı tarafından, yatırım izleme ve koordinasyon başkanlıklarının görev ve sorumluluklarını yerine getirebilmesi için her yıl İçişleri Bakanlığı bütçesine yeterli ödenek konulur (6360 sayılı Kanun Md. 34). Merkezi idarenin, yerel yönetime müdahale ucu gibi tasarlanmış olan yeni yapılanmanın ortaya çıkışının, İl Özel İdareleri’nin kapatılmasından kaynaklanacak boşluğu ortadan kaldırmak olduğu görülmektedir. Ancak bu yeni yapı, bir yandan yerelleşme iddiaları bulunan bir anlayışın, aslen merkezileşmeye doğru gittiğini de göstermektedir.

Merkezileşme eğiliminin diğer bir örneği şu şekilde gerçekleşmektedir; ildeki kamu kurum ve kuruluşları tarafindan yürütülmesi gereken bazı hizmetlerin ilgili kuruluş tarafından yürütülmediği ya da yürütülemediği fark edilirse vali tarafından bu hizmetlerin sunulması görevi yatırım izleme ve koordinasyon başkanlığına verilir ve hizmet sonucunda ortaya çıkan maliyetler ilgili kuruluştan tahsil edilir. Bu kapsamda belediyenin yürütmesi gereken hizmetlerde meydana gelebilecek aksaklıklar valinin isteği üzerine Yatırım İzleme ve Koordinasyon Başkanlığı tarafından yerine getirilecektir. Yerine getirilmeyen hizmet ile ilgili ortaya çıkan maliyetler belediye hesabına aktarılacak olan il bank hesabından kesinti yapılarak karşılanacaktır. Bu düzenleme ile merkezi yönetim doğrudan yerel yönetimlerin bütçelerine müdahale imkânı kazanacak ve mali özerkliğin önünde yeni bir engel konulmuş olacaktır (Kızılboğa ve Özaslan, 2013: 801).

\subsection{HIZMETTE ETKINLIK ve VERIMLILIK AÇISINDAN MEYDANA GELEN DEĞİSíKLIKLER}

6360 sayılı Büyükşehir Belediye Kanunu ile ölçek ekonomileri ile kamusal harcamaların azalacağı ve hizmet maliyetlerinin düşürüleceği öngörülmektedir. 6360 sayılı Kanun'un genel gerekçesinde ölçek ekonomisine ilişkin şu hükümler yer almaktadır; "Büyükşehirlerin temel niteliklerinden birisi, sınırları içinde birden çok yerleşim merkezi ve yönetim birimi bulundurmasıdır. Büyükşehir sınırları içinde yer alan yerel yönetimler küçük ölçekli planlar yapabilseler de bu planların geniş bir çerçeve içinde bütüncül olarak tüm büyükşehir bölgesini kapsayan ve makro politikaları belirleyen bir çerçeve içinde ele alınmasına ihtiyaç duyulmaktadır.

Büyükşehirleri zorunlu kılan temel hususlardan bir başkası, belli bir coğrafi alanda çok sayıda yerel yönetimin yetkili olması halinde planlama ve koordinasyonun sağlanamayışı ve ölçek ekonomisinden yeterince yararlanılamaması nedeniyle kaynak israfına yol açılmasıdır. Sanayileşme, ulaşım ve çevre gibi artan sorunların, hizmet üretme kapasitesi ve yeterli mali kaynaktan yoksun küçük ölçekli yerel yönetimlerce çözülmesi mümkün görünmemektedir. Bu durum kaynakların etkin ve yerinde kullanımını engellemekte, küçük yerleşim birimlerinin yanı sıra nüfusun yoğun olduğu büyükşsehirlerde de ciddi yönetim sorunlarına yol açmaktadır. Uygun büyüklükte hizmet üretecek güçlü yerel yönetimlerin olmayışı, halkın yerel yönetimlerden beklediği kamu hizmetlerinin kaliteli bir biçimde karşılanamaması ve kamu hizmetlerinin sunumunda koordinasyon eksikliği sorunlarını ortaya çıkarmaktadır. Bu çerçevede yönetim, planlama ve koordinasyon açısından belediye sınırı mülki sınır olacak biçimde optimal ölçekte hizmet üretebilecek güçlü 
yerel yönetim yapılarının varlığına ihtiyaç duyulmaktadır. Büyükşehir alanında sunulan hizmetlerin tek merkezden yürütülmesi ile ortaya çıkan ölçek ekonomileri sayesinde hizmetlerde etkinlik, koordinasyon ve kalite yükselecek, daha az kaynak ile daha çok ve daha kaliteli hizmet sunulması mümkün hale gelebilecektir. Hâlihazırda birden fazla merkezden verilen hizmetlerin daha büyük ve ideal ölçekteki bir merkez tarafindan verilmesi birim maliyetler ve kişi başına kamusal harcamaları da azaltacaktır.

Hizmet etkinliğinin ön planda olduğu ölçek ekonomilerinin oluşturulduğu 6360 sayılı Kanun'da ölçek ekonomileri ile birlikte hizmetin faydasının yayıldığı alan da dikkate alınması gereken önemli bir unsurdur (Arıkboğa, 2013). Ancak bu alanda her hizmet için farklı bir optimal büyüklük belirlenmesi gerekmekte ve bunun matematiksel olarak ölçümü zorlaşmaktadır. Bu kapsamda ortaya çıkan optimal belediye kavramı genel olarak, şehir büyüklüğü, şehir bütünlügü, belediye büyüklügü gibi farklı şekillerde adlandırılmaktadır. Optimal büyüklük dendiğinde anlatılmak istenen ise, en uygun büyüklük kavramı olmaktadır (Atmaca, 2013: 170). Optimal büyüklük şu şekilde belirlenebilir; belirli bir alanda yerleşik nüfusa, bölünmezlik niteliğine sahip bir kamu hizmeti sunulduğu ve hizmetin maliyetinin sabit olduğu varsayılır. Bundan dolayı kişi başına hizmet maliyeti (Ortalama Maliyet-OM) alan nüfusu arttıkça, marjinal maliyetteki düşüşe bağlı olarak azalacaktır. Diğer bir ifadeyle, belirli bir bölgedeki kamusal hizmet maliyeti toplamını " $\mathrm{M}$ " olarak belirleyip, o bölgedeki yaşayan kişi sayısını " $n$ " dersek, kişi başına düşen ortalama maliyet " $\mathrm{M} / \mathrm{n}$ " olarak belirlenir. Böylece nüfus arttıça ortalama maliyet azalır. Ancak nüfusun belirli bir noktaya kadar artması ortalama maliyeti düşürür. Belirli bir noktadan sonra ortalama maliyet artmaya başlar. İşte bu noktada oluşan maliyete optimal maliyet denir. Matematiksel olarak nüfus arttıkça ortalama maliyetin azalması gerekmektedir. Ancak nüfus yoğunlaşmasının artması kalabalıklaşma maliyetinin oluşmasına neden olacaktır. Bu maliyet türü nüfusun artması ile birlikte ortaya çıkan ek iş gücü, malzeme, hizmet kalitesinin bozulmas1, idari kapasitenin yetersiz kalması, çevre kirlenmesi, trafik yoğunluğu gibi nedenlerden kaynaklanmaktadır (Topal, 2005: 451-454). 6360 sayılı Kanun'da ve bundan önceki yerel yönetim kanunlarında bir yerel yönetim birimi kurulurken nüfus ölçütü dikkate alınmış ve optimal büyüklük ile nüfus ilişkilendirilmiştir.

En uygun şehir büyüklügünün ne olduğunu belirlemek hemen hemen imkânsızdır. Bugüne kadar yapılan çalışmalar incelendiğinde aynı hizmet türü için bile farklı nüfus büyüklükleri verilmiştir. Yine de çeşitli çalışmalarda elde edilen rakamlar, çoğunlukla 40.000 ile 500.000 arasında değişmektedir ki bu rakam 1.000.000'a çıktığı gibi 10.000'e kadar düşmektedir. Bu çıkarımdan hareketle, birkaç bin nüfuslu şehirlerin ve bir milyonu aşan şehirlerin çoğunun belediye hizmetleri açısından optimal olmadığı söylenebilir (Özgür, 2008: 8). En uygun büyüklük konusunda İtalya'daki belediyeler üzerine İtalya İçişleri Bakanlığı tarafından 1985 'te yapılan bir çalışmada ise belediyelerin nüfus büyüklükleri kişi başına maliyet arasında "U" eğrisi biçiminde bir ilişki saptanmış ve buna göre nüfusu 5.000'in altında olan belediyelerde kişi başına harcamanın yüksek düzeyde çıktığı ve 5.000 sınırına doğru yaklaştıkça bu miktarın düştüğ̈̈ ve ancak 5.000 sınırından sonra yeniden yükselmeye başladığı belirlenmiştir (Arıkboğa, 2007b: 3)

Belediye yerleşimleri ve ölçekleri konusunda 2002 yılında Canpolat tarafindan yapılan alan araştırmasında; küçük ölçekli belediyelerin önemli bir kısmının, büyük belediyelerin (ilçe, il, büyükşehir) etrafında kümelendiği, birçok yerel hizmeti yürütemedikleri, teknik eleman istihdam etme kapasitesinin çok düşük olduğu, katılım ortamı, halkın katılım kapasitesi ve belediyelerin katılım ortamı oluşturma yeterliliğinin çok düşük olduğu, mali yapıları büyük ölçüde genel bütçe vergi gelirlerine bağımlı olduğu, öz gelir elde etme kapasitesi düşük olduğu ve cari harcamaların bütçe içinde çok büyük pay tutmakta olduğu sonuçlarına ulaşılmıştır (Canpolat, 2010: 94). Güven (1982: 43-44) küçük ölçekli belediyelerle ilgili bu sorunların nedenini; nitelikli personel yetersizliği, mali yetersizlikler, alan ve nüfus yetersizlikleri olarak üç temel etmene dayandırmıştır.

Kahramanmaraş İlindeki 2014 yılı öncesi belediye yerleşmeleri incelendiğinde, nüfus açısından küçük ölçekli belde belediyelerinin genellikle il ve ilçe belediyelerinin yakınlarında kümelendikleri görülür. Özellikle il merkezine yakın Çimen Dağı'nın kuzeye bakan yamaçlarında, Elbistan, Afşin ve Göksun ilçe merkezlerinin yakınlarında toplandığı görülmektedir (Şekil 8). Bu belediyelerin mali yapılarının genel olarak bütçe gelirlerine bağlı olduğu, teknik eleman ve araç parkı bakımından yetersiz olduğu ve gerekli hizmeti üretemediği belirlenmiştir. 


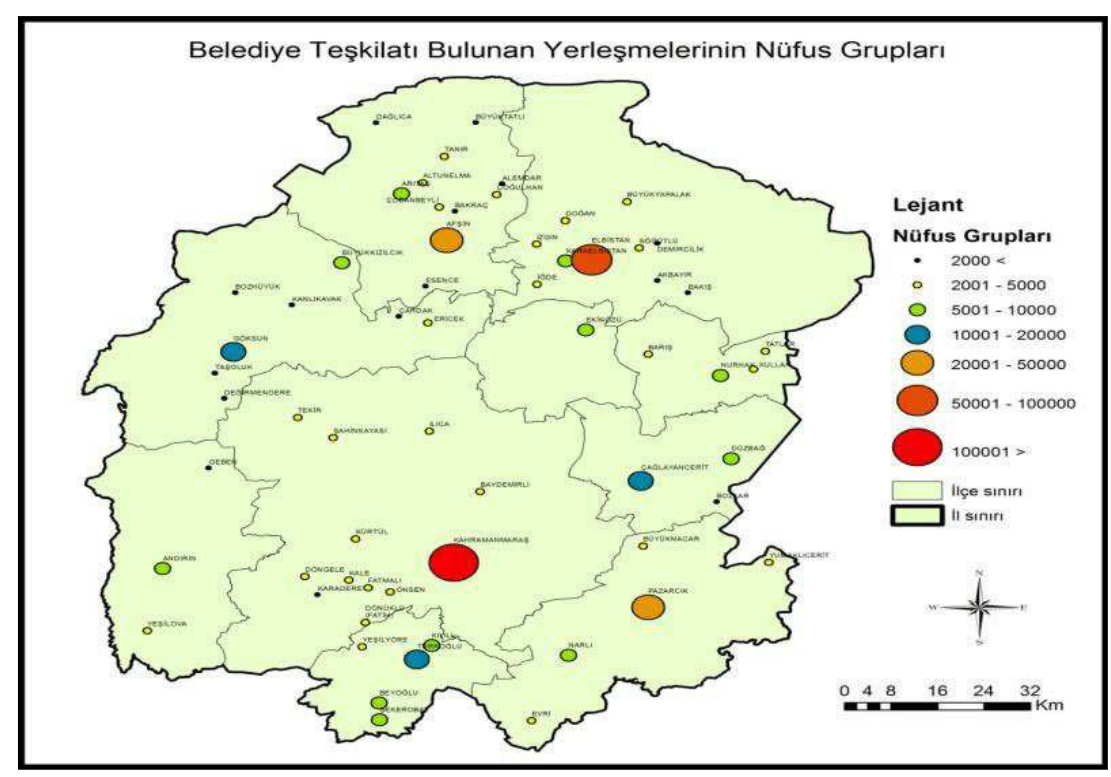

Şekil 8. Kahramanmaraş’ta Belediye Teşkilatı Bulunan Yerleşmelerin Nüfus Gruplarına Göre Dağılış Haritasıı

Kahramanmaraş'ın 6360 sayı1ı Kanun öncesi durumuna bakıldığında, belde belediyeleri Kahramanmaraş ili nüfusunun \%14,1'ini oluşturmaktadır. Türkiye'deki yasal mevzuata göre bir değerlendirme yapılırsa; 5393 sayılı Belediye Kanunu ile belediye kurulabilmesi için İtalya'daki araştırmaya benzer bir ölçüt alınarak 5000 nüfusa ihtiyaç duyulmuştur. Optimal büyüklük 5000 olarak belirlenirse, Kahramanmaraş'ta 44 belde belediyesinin bu kriteri sağlayamadığ görülmektedir. Hizmetin etkin ve verimli sunulması için belirlenen 5000 sayısına ulaşan belde belediye sayısı ise 8'dir. Öte yandan, optimal büyüklüğü 10.000 olarak kabul edilirse, Kahramanmaraş’taki belde belediyelerinin hiç biri etkin ve verimli hizmet sunma konusunda gereken kriteri sağlayamayacaktır. Bu anlamda Kahramanmaraş ili belde belediyelerinde hizmet maliyetlerinin arttığı ve etkinliğin azaldığı söylenebilir.

Tablo 5. Kahramanmaraş İlinde 6360 Sayılı Kanun Öncesi Belde Belediyelerin Durumu

\begin{tabular}{|c|c|c|c|c|c|c|c|c|c|}
\hline İlçe & Belediye & Nüfus & $\begin{array}{l}\text { İl } \\
\text { Merkezine } \\
\text { Uzaklık }\end{array}$ & $\begin{array}{l}\text { İlçe } \\
\text { Merkezine } \\
\text { Uzaklık }\end{array}$ & İlçe & Belediye & Nüfus & $\begin{array}{l}\text { İl } \\
\text { Merkezine } \\
\text { Uzaklık }\end{array}$ & $\begin{array}{l}\text { İlçe } \\
\text { Merkezine } \\
\text { Uzaklık }\end{array}$ \\
\hline \multirow[t]{11}{*}{ Merkez } & Baydemirli & 3.249 & 12 & 12 & \multirow[t]{9}{*}{ Elbistan } & Akbayır & 1.410 & 174 & 13 \\
\hline & Döngele & 2.236 & 50 & 50 & & Bakış & 1.644 & 182 & 22 \\
\hline & Fatih & 4.756 & 29 & 29 & & Büyükyapalak & 2.452 & 175 & 18 \\
\hline & Fatmalı & 3.899 & 50 & 50 & & Demircilik & 1.706 & 173 & 13 \\
\hline & Ilica & 2.614 & 43 & 43 & & Doğan & 2.646 & 168 & 12 \\
\hline & Kale & 4.128 & 27 & 27 & & Izgin & 2.164 & 156 & 12 \\
\hline & Karadere & 1.225 & 41 & 41 & & İğde & 2.179 & 163 & 16 \\
\hline & Kürtül & 2.517 & 25 & 25 & & Karaelbistan & 6.002 & 156 & 6 \\
\hline & Önsen & 4.235 & 22 & 22 & & Söğütlü & 2.279 & 169 & 9 \\
\hline & Şahinkayası & 2.919 & 57 & 57 & \multirow[t]{7}{*}{ Göksun } & Bozhüyük & 1.191 & 109 & 17 \\
\hline & Tekir & 3.402 & 63 & 63 & & Büyükkızılcık & 4.918 & 121 & 31 \\
\hline \multirow[t]{5}{*}{ Afşin } & Alemdar & 763 & 158 & 20 & & Çardak & 1.599 & 121 & 32 \\
\hline & Altınelma & 2467 & 138 & 15 & & Değirmendere & 1.804 & 85 & 12 \\
\hline & Arıtaş & 5.137 & 153 & 15 & & Ericek & 2.889 & 127 & 38 \\
\hline & Bakraç & 1.332 & 145 & 7 & & Kanlıkavak & 1.803 & 106 & 17 \\
\hline & Büyüktatlı & 1.285 & 176 & 39 & & Taşoluk & 1.325 & 92 & 5 \\
\hline
\end{tabular}




\begin{tabular}{|c|c|c|c|c|c|c|c|c|c|}
\hline & Çobanbeyli & 3.119 & 146 & 8 & \multirow[t]{3}{*}{ Nurhak } & Barış & 2.009 & 163 & 12 \\
\hline & Çoğulhan & 1.986 & 154 & 16 & & Kullar & 2.555 & 147 & 7 \\
\hline & Dağlıca & 1.011 & 173 & 37 & & Tatlar & 2.706 & 149 & 12 \\
\hline & Esence & 763 & 132 & 13 & \multirow[t]{4}{*}{ Pazarcık } & Büyüknacar & 2.025 & 42 & 24 \\
\hline & Tanır & 2.362 & 158 & 20 & & Evri & 2.311 & 48 & 37 \\
\hline \multirow[t]{2}{*}{ Andırın } & Geben & 1.840 & 76 & 29 & & Narlı & 7.197 & 30 & 20 \\
\hline & Yeşilova & 2.244 & 91 & 20 & & Yumaklicerit & 2.239 & 76 & 29 \\
\hline \multirow[t]{2}{*}{ Çağlayancerit } & Bozlar & 1.881 & 73 & 16 & \multirow[t]{4}{*}{ Türkoğlu } & Beyoğlu & 8.323 & 37 & 16 \\
\hline & Helete & 5.304 & 84 & 20 & & Kililı & 6.324 & 21 & 4 \\
\hline \multirow[t]{3}{*}{ Ekinözü } & \multirow[t]{3}{*}{ Belde yok } & & & & & Şekeroba & 7.530 & 41 & 20 \\
\hline & & & & & & Yeşilyöre & 3.848 & 35 & 12 \\
\hline & & & & & Toplam & Belde Bel. & 151.752 & & \\
\hline
\end{tabular}

Kaynak: TUIK, 2013'den nüfus verileri ve https://maps.google.com'den uzaklıklar hesaplanmıştır.

Belde belediyelerinin il ve ilçelere olan uzaklıkları incelendiğinde ise il merkezine uzaklığ $120 \mathrm{~km}$ üzerinde olan 25 belde belediyesi bulunmaktadır (Tablo 5). Bununla birlikte Kahramanmaraş arazisinin büyük çoğunluğunun dağlık ve ormanlık olması büyükşehir belediyesinin bu yerlere hizmet sunumunda sıkıntılara yol açacaktır. Araştırmanın konusunu dağıtmamak adına köylerin nüfusu, il ve ilçe merkezine uzaklığı belirtilmemiştir. Ancak köylerin il merkezine uzaklığı da belde belediyelerinkine benzer bir sonuç ortaya koyacaktır.

Hizmetin faydasının yayıldığı alana bakıldığı zaman, her bir hizmetin faydasının yayıldığı alan birbirinden farklıdır. Bazı hizmetlerin faydası daha geniş alanlara yayılabilir, bazı hizmetler için ise tersi söylenebilir. Bazı hizmetlerin faydası tüm ulusa yayılırken (dış politika, savunma vs.) bazı hizmetlerin faydası ise mahalle ya da sokak ölçeği ile sınırlı kalabilmektedir (Arıkboğa, 2013). Bu değerlendirmeye göre il ya da ilçe sınırlarında sunulması gereken bazı hizmetlerin belde belediyeleri tarafından yerine getirilmesi hem hizmetin faydasını düşürmekte, hem de maliyeti yükseltmektedir. Bu bakımdan 6360 sayılı Kanun gerekçesinde de belirtildiği gibi ölçek ekonomilerinin oluşturulması için Kahramanmaraş İlindeki 476 köy ve 52 belde belediyesi kapatılarak mülki sınırları içerisindeki ilçe belediyelerinin mahallesi haline dönüştürülmüş ve bu bölgelerin hizmet sunumu hizmetin niteliğine göre büyükşehir belediyesine ya da büyükşehir ilçe belediyelerine bırakılmıştır.

Kahramanmaraş’ta belediye örgütlü yerleşmeleri coğrafi fonksiyonlarına göre ayrım yapabilmenin en kolay ve pratik yolu çalışan nüfusu ekonomik faaliyetlere göre sınıflandırmaktır. Bu çalışmada belediye örgütlü yerleşmelerin coğrafi fonksiyonlarına göre ayrımı yapılırken, hizmet ve sanayide çalışanların toplamı \%40'1n altında ise kırsal yerleşme, \%40-60 arasında ise kasaba yerleşmesi, \%60'dan fazla ise şehir yerleşmesi olarak sınıflanmıştır. Bu sınıflandırmaya göre; il merkezi başta olmak üzere ilçe merkezlerinin (Çağlayancerit hariç) şehir yerleşmesi, Çağlayancerit ilçe merkezi ve Afşin'in Alemdar beldesinin kasaba yerleşmesi, diğer yerleşmelerin ise kırsal yerleşme özellikleri taşıdığı belirlenmiştir (Tablo 6, Şekil 3). Fonksiyonel özelliklere göre belediyelerin dağılımı incelendiğinde; belediye teşkilatı bulunan kırsal yerleşmelerin Kahramanmaraş şehrinin güneyinde yer alan Çimen Dağ 1 eteklerindeki ve Afşin-Elbistan havzasında yoğunlaştığı görülmektedir.

Büyükşehir Belediye Kanunu ile fonksiyonel olarak kasaba ve kırsal özellik taşıyan belediyeler kaldırılmıştır. Fakat Türkiye'deki belediyecilik uygulaması geniş kırsal alanlara hizmet vermeye çok da uygun değildir. Yerel yönetimlerin dünyada gelişimine ve pratikleri incelendiğinde kırsal alanlara ilişkin bir belediyecilik anlayışının neredeyse hiç gelişmediği görülür. Kırsal alanlar için kırsal politikaları uygulayabilen ve gelişime açık olan yeni yönetim birimlerine ihtiyaç vardır (Ökmen ve Parlak, 2013: 316). $\mathrm{Bu}$ bakımdan kırsal politikaların uygulanmasında sıkıntılara neden olacak mahalle yönetiminin köy ve beldelere çok da uygun olmadığı göze çarpmaktadır. Bununla birlikte mahalleye dönüştürülen belde belediyelerinin yüzölçümleri kentsel alanlardaki mahallelerde olduğu gibi az değildir. Bu bölgelerde nüfus 
yoğunluğu azalmaktadır. Belediye ile olan ilişkilerde kilit bir rolde olması gereken mahalle yönetiminin bu kırsal alanlarda hizmetin demokratik, etkin ve verimli sunulması noktasında güçlüklerle karşılaşacaktır. Bununla birlikte kırsal alan özelliği gösteren köylerin mevcut kentsel yapıya uygun bir idari birime dönüştürülmesi çeşitli kırsal sorunlara neden olabileceği öngörülmekte olup uygulama sonrası ortaya çıkacak sorunlar belirlenerek bu bölgelerin yeni bir mevzuatla büyükşehir belediyelerine bağlanması sağlanabilir.

Tablo 6. Kahramanmaraş'ta Belediye Teşkilatı Bulunan Yerleşmelerde Çalışanların Sektörlere Göre

\begin{tabular}{|c|c|c|c|c|c|}
\hline \multicolumn{6}{|c|}{ Dağılımı } \\
\hline İlçe & Belediye & Hizmet \% & Sanayi \% & Hizmet+Sanayi & Tarım \% \\
\hline \multirow[t]{12}{*}{ Kahramanmaraş-Merkez } & Kahramanmaraş & 48 & 47 & 95 & 5 \\
\hline & Baydemirli (B) & 3 & 1 & 4 & 96 \\
\hline & Fatih (B) & 6 & 4 & 10 & 90 \\
\hline & Fatmalı (B) & 7 & 7 & 14 & 86 \\
\hline & Kale (B) & 6 & 7 & 13 & 87 \\
\hline & Karadere (B) & 5 & 8 & 13 & 87 \\
\hline & Kürtül (B) & 8 & 11 & 19 & 81 \\
\hline & Önsen (B) & 7 & 12 & 19 & 81 \\
\hline & Şahinkayası (B) & 5 & 3 & 8 & 92 \\
\hline & Tekir (B) & 10 & 3 & 13 & 87 \\
\hline & Ilica (B) & 8 & 6 & 14 & 86 \\
\hline & Döngele (B) & 9 & 7 & 16 & 84 \\
\hline \multirow[t]{11}{*}{ Afşsin } & Afşsin & 67 & 24 & 91 & 9 \\
\hline & Alemdar (B) & 47 & 7 & 53 & 47 \\
\hline & Arıtaş (B) & 9 & 3 & 13 & 87 \\
\hline & Bakraç (B) & 6 & 4 & 11 & 89 \\
\hline & Çobanbeyli (B) & 8 & 4 & 12 & 88 \\
\hline & Çoğulhan (B) & 34 & 3 & 36 & 64 \\
\hline & Esence (B) & 6 & 1 & 7 & 93 \\
\hline & Altınelma (B) & 5 & 3 & 8 & 92 \\
\hline & Büyüktatlı (B) & 7 & 2 & 9 & 91 \\
\hline & Dağlıca (B) & 5 & 2 & 6 & 94 \\
\hline & Tanır $(\mathrm{Bm})$ & 13 & 4 & 17 & 83 \\
\hline \multirow[t]{3}{*}{ Andırın } & Andırın & 67 & 18 & 84 & 16 \\
\hline & Geben (B) & 9 & 3 & 12 & 88 \\
\hline & Yeşilova (B) & 14 & 3 & 17 & 83 \\
\hline \multirow[t]{3}{*}{ Çağlayancerit } & Çağlayancerit & 33 & 21 & 55 & 45 \\
\hline & Bozlar (B) & 2 & 2 & 4 & 96 \\
\hline & Helete & 7 & 1 & 7 & 93 \\
\hline Ekinözü & Ekinözü & 46 & 19 & 65 & 35 \\
\hline \multirow[t]{4}{*}{ Elbistan } & Elbistan & 60 & 30 & 89 & 11 \\
\hline & Bakış (B) & 2 & 3 & 5 & 95 \\
\hline & Akbayır (B) & 7 & 5 & 11 & 89 \\
\hline & Büyükyapalak (B) & 7 & 3 & 10 & 90 \\
\hline
\end{tabular}




\begin{tabular}{|c|c|c|c|c|c|}
\hline & Demircilik (B) & 8 & 2 & 11 & 89 \\
\hline & Doğan (B) & 18 & 3 & 21 & 79 \\
\hline & İğde (B) & 7 & 4 & 11 & 89 \\
\hline & Izgin (B) & 4 & 2 & 6 & 94 \\
\hline & Karaelbistan (B) & 8 & 8 & 16 & 84 \\
\hline & Söğütlü (B) & 9 & 5 & 14 & 86 \\
\hline \multirow[t]{8}{*}{ Göksun } & Göksun & 49 & 31 & 80 & 20 \\
\hline & Çardak (Bm) & 15 & 2 & 17 & 83 \\
\hline & Ericek (B) & 7 & 1 & 9 & 91 \\
\hline & Bozhüyük (B) & 7 & 7 & 14 & 86 \\
\hline & Büyükkızılcık (B) & 4 & 2 & 6 & 94 \\
\hline & Değirmendere (B) & 10 & 2 & 12 & 88 \\
\hline & Kanlıkavak (B) & 7 & 3 & 11 & 89 \\
\hline & Taşoluk (B) & 9 & 4 & 13 & 87 \\
\hline \multirow[t]{3}{*}{ Nurhak } & Nurhak & 48 & 20 & 68 & 32 \\
\hline & Barıș (B) & 6 & 4 & 10 & 90 \\
\hline & Kullar-Tatlar (B) & 3 & 1 & 5 & 95 \\
\hline \multirow[t]{5}{*}{ Pazarcık } & Pazarcık & 51 & 33 & 84 & 16 \\
\hline & Büyüknacar (B) & 3 & 1 & 4 & 96 \\
\hline & Yumaklicerit (B) & 6 & 2 & 8 & 92 \\
\hline & Evri (B) & 5 & 3 & 8 & 92 \\
\hline & Narlı (Bm) & 10 & 7 & 17 & 83 \\
\hline \multirow[t]{5}{*}{ Türkoğlu } & Türkoğlu & 48 & 27 & 75 & 25 \\
\hline & Beyoğlu (B) & 11 & 8 & 18 & 82 \\
\hline & Kil11 (B) & 7 & 18 & 25 & 75 \\
\hline & Şekeroba (B) & 7 & 9 & 16 & 84 \\
\hline & Yeşilyöre (B) & 7 & 9 & 16 & 84 \\
\hline
\end{tabular}




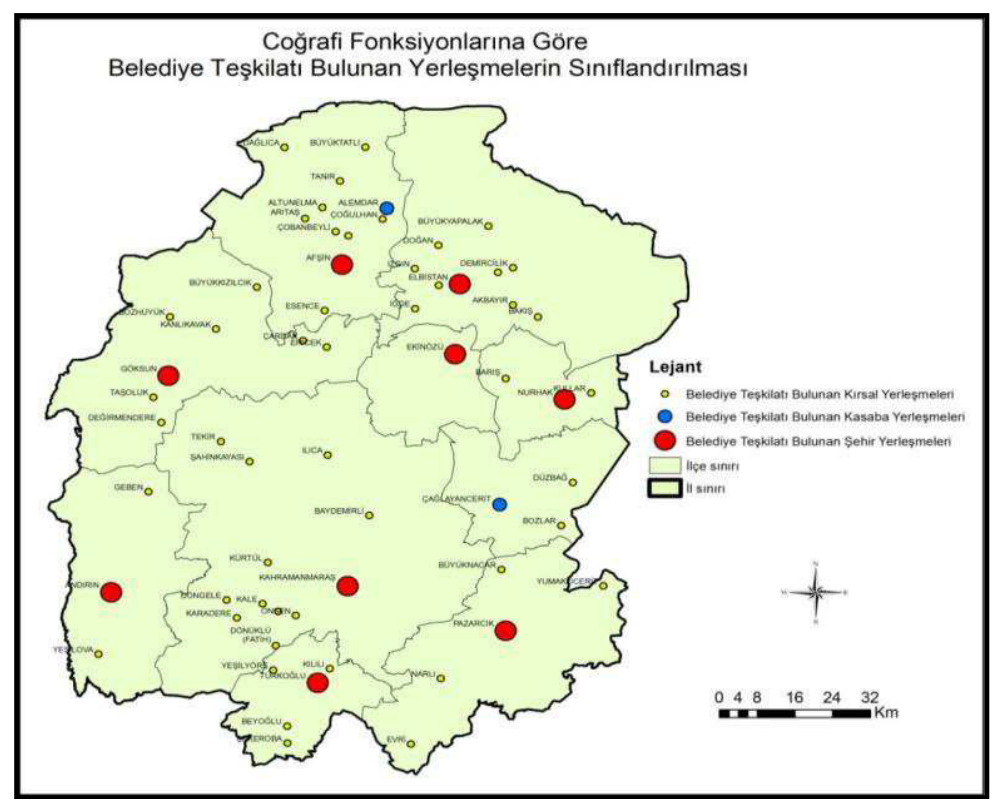

Şekil 9. Coğrafi Fonksiyonlarına Göre Belediye Teşkilatı Bulunan Yerleşmelerin Dağılış Haritası

Tablo 7. 6360 Sayılı Kanun Sonrası Kahramanmaraş'ta Belediyelerin Durumu

\begin{tabular}{|l|l|l|l|}
\hline İlçe & Nüfus & Yüzölçümü(km & İl Merkezine Uzaklık \\
\hline Afşin & 82.662 & 1.434 & 143 \\
\hline Andırın & 35.943 & 1.198 & 81 \\
\hline Çağlayancerit & 25.276 & 419 & 64 \\
\hline Dulkadiroğlu & 216.701 & 1.313 & İl Merkezinde \\
\hline Ekinözü & 13.461 & 598 & 174 \\
\hline Elbistan & 140.493 & 2.328 & 158 \\
\hline Göksun & 53.157 & 1.949 & 89 \\
\hline Nurhak & 13.414 & 1225 & 201 \\
\hline Onikişubat & 357.870 & 1.40 & İl Merkezinde \\
\hline Pazarcık & 68.843 & 1.739 & 46 \\
\hline Türkoğlu & 67.886 & 603 & 57 \\
\hline Toplam & 1.075 .706 & 14.346 & \\
& & & \\
\hline
\end{tabular}

Kaynak: TUiK, 2013 ve Harita Genel Komutanlığı

Kahramanmaraş'ta ilçelerin nüfusu ve il merkezine uzaklığı incelendiği zaman Nurhak, Elbistan, Afşin ilçelerinin merkeze olan uzaklığının Türkiye'de bazı illerin birbirleri ile olan uzaklığından daha fazla olduğu görülmektedir. Bununla birlikte bu bölgelerin topografyasının dağlık olması hizmetin zamanında sunulmasına engel olacaktır. İl merkezine çok uzak olmakla birlikte nüfusu 13.000 dolaylarında olan Nurhak ve Ekinözü ilçelerine sunulacak hizmetin maliyetindeki artış diğer bölgelerden sağlanacak desteklerle giderilmeye çalış1lacaktır. Ancak bu ilçelerin nüfusunun 6360 sayılı Kanun'da belirlenen 20.000 nüfus miktarının altında olması ve il merkezine uzaklıklarının sirasıyla 174 ve $201 \mathrm{~km}$ olması bu bölgelerde hizmetin faydasının yayıldığı alan ve maliyetler açısından yeni sorunlara neden olacaktır. Dulkadiroğlu ve Onikişubat ilçelerinde hizmet maliyetine kalabalıklaşma maliyeti de eklenince hizmet sunumunda sorunlar oluşacaktır. Birleşme temeline dayanan büyükşsehir belediye anlayışının mevcut il belediyelerinin bölünerek yeni büyükşehir ilçe belediyeleri ile hizmet maliyetlerinin düşürülmesini beklenmesi çelişki gibi görünmektedir. Ancak hizmet maliyetine eklenecek kalabalıklaşma maliyeti ile Kahramanmaraş ili 
merkezinin tek bir ilçe belediyesi tarafindan yönetilmesi uygun görülmemektedir. Bununla birlikte Kahramanmaraş merkezde oluşturulan Dulkadiroğlu ve Onikişubat ilçelerinin nüfuslarının diğer ilçelerin çok üzerinde olması ve ildeki hizmet ve sanayi sektörünün büyük çoğunluğunun bu ilçelere dayanması vergi gelirlerinin bu bölgelerden sağlanmasına ancak hizmetin ilin diğer kısımlarına yayılmasına neden olacaktır (Tablo 7).

\subsection{GÖREV, YETKİ ve SORUMLULUK AÇISINDA MEYDANA GELEN DEĞİŞIKLİKLER}

Büyükşehir belediye sistemi Kahramanmaraş’taki belediyelerin görev ve yetki bölüşümünü yeniden şekillendirmektedir. Tepede bir büyükşehir belediyesi ve ona bağlı büyükşehir ilçe belediyeleri gibi iki kademeli bir yapı kurulmuştur. Büyükşehir belediyesi büyükşehir sınırları içinde mahalli müşterek ihtiyaçların karşılanması bakımından oldukça geniş yetkilere sahiptir. İlçe belediyelerine ise büyükşehir belediyelerine verilen görevlerin dışında kalan sınırlı sayıda görevler kalmaktadır. Özetle büyükşehir belediyesinin rolü uyum ve koordinasyonun sağlanması ile birlikte daha merkeziyetçi bir yapının sağlanması yönündedir. Büyükşehir Belediye Kanunu'nda da bu durum şu şekilde ifade edilmektedir. "Büyükşehir kapsamındaki belediyeler arasında hizmetlerin yerine getirilmesi bakımından uyum ve koordinasyon, büyükşehir belediyesi tarafından sağlanır. Büyükşsehir belediyesi ile ilçe belediyeleri veya ilçe belediyelerinin kendi aralarında hizmetlerin yürütülmesiyle ilgili ihtilaf çıkması durumunda, büyükşehir belediye meclisi yönlendirici ve düzenleyici kararlar almaya yetkilidir.” (6360 sayılı Kanun Md. 11).

Büyükșehir belediyesinin yetki alanındaki mahalleleri ilçe merkezine bağlayan yollar, meydan, bulvar, cadde ve ana yolları yapmak, yaptırmak, bakım ve onarımı ile bu yolların temizliği ve karla mücadele çalışmalarını yürütmek; kentsel tasarım projelerine uygun olarak bu yerlere cephesi bulunan yapılara ilişkin yükümlülükler koymak; ilân ve reklam asılacak yerleri ve bunların şekil ve ebadını belirlemek; meydan, bulvar, cadde, yol ve sokak ad ve numaraları ile bunlar üzerindeki binalara numara verilmesi işlerini gerçekleştirmek büyükşehir belediyesinin yetkisindedir. Afet riski taşıyan veya can ve mal güvenliği açısından tehlike oluşturan binaları tahliye etme ve yıkım konusunda ilçe belediyelerinin talepleri hâlinde her türlü desteği sağlamak, büyükşehir ve ilçe belediyeleri tarım ve hayvancılı̆̆ 1 desteklemek amacıyla her türlü faaliyet ve hizmette bulunabilme yetkisine sahiptir. Büyükşehir içindeki kara, deniz, su, göl ve demiryolu üzerindeki her türlü taşımacılık hizmetlerinin koordinasyon içinde yürütülmesi amacıyla Ulaşım Koordinasyon Merkezi kurulur.

Öte yandan 6360 sayılı Kanun ile büyükşehir belediye meclisi kararı ile bazı yetkilerin ilçe belediyelerine devredilebilmesi de söz konusudur. Yük ve yolcu terminalleri, kapalı ve açık otoparklar yapmak, yaptırmak işletmek ve işlettirmek veya ruhsat vermek; mezarlık alanlarını tespit etmek, mezarlıklar tesis etmek, işletmek, işlettirmek, defin ile ilgili hizmetleri yürütmek, her çeşit toptanci hallerini ve mezbahaları yapmak, yaptırmak, işletmek veya işlettirmek, imar planında gösterilen yerlerde yapılacak olan özel hal ve mezbahaları ruhsatlandırmak ve denetlemek ile temizlik hizmetleri ve numaralandırmaya ilişkin görevler devredebilir görevler arasındadır.

Büyükşehir Belediye Kanunu ile Kahramanmaraş belediyeleri arasında değişen görev, yetki ve sorumluluk dağılımının rantabl bir şekilde sürdürülmesi mümkün görülmemektedir. Büyükşehir belediyesinin yükümlü olduğu hizmetlerini sorumlu olduğu bölgelere götürmesinde ilin coğrafi büyüklügü, topografik çeşitliliği ve mekânsal uzaklığı hizmetlerin kalite ve birim maliyeti kadar hizmetin ihtiyaç olduğu zamanda ulaştırılmasını da etkileyecektir.

\subsection{TEMSİL VE KATILIM AÇISINDAN MEYDANA GELEN DEĞİşiKLİK}

Büyükşehirlerin il mülki sınırlarını kapsayacak şekilde genişletilmesi ile yerel demokrasinin işlerlik kazanması ve subsidiarite ilkesinin uygulanması bakımdan kapatılan belediyeler sorunlar oluşturabilir. Yerel yöneticilerin artan yetki ve sorumlulukları karşısında merkezden uzaklaştıkça halkın seçtiği kişilere olan uzaklığı ve hizmet yakınlığından (subsidiarite) söz etmek mümkün olmayabilir (Karagel, 2012: 11). Bu konuda belediyeler arasında temsil adaletsizliğinin nasıl olduğunu Tablo 8 ortaya koymaktadır.

Tablo 8. İlçe Belediyelerinin Büyükşehir Belediye Meclisine Gönderecekleri Üye Sayısı 


\begin{tabular}{|l|c|c|c|}
\hline Belediye Nüfusu & Meclis Üye Sayısı & $\begin{array}{l}\text { Büyükşehir Belediye Meclisine } \\
\text { Gönderilen Üye Sayısı }\end{array}$ & Ortalama Temsil (Nüfus/Temsilci Sayısı) \\
\hline $0-10.000$ & 9 & 2 & 5.000 \\
\hline $10.001-20.000$ & 11 & 3 & 6.666 \\
\hline $20.001-50.000$ & 15 & 4 & 12.500 \\
\hline $50.001-100.000$ & 25 & 6 & 36.666 \\
\hline $100.001-250.000$ & 31 & 7 & 62.500 \\
\hline $250.001-500.000$ & 37 & 8 & 100.000 \\
\hline $500.001-1.000 .000$ & 45 & 10 & 83.333 \\
\hline $1.000 .001+$ & 55 & 12 & \\
\hline
\end{tabular}

Kaynak: Arıkboğa, 2009: 741

Tablo 8 incelendiğinde, ilçe belediyelerinin nüfusları arttıç̧a, büyükşehir belediye meclisinde oransal olarak daha az üyeyle temsil edildikleri görülmektedir. Büyükşehir belediye meclisindeki temsil sistemi, küçük nüfuslu ilçe belediyelerini kayırıcı sonuçlar doğurmasının yanında nüfusu fazla olan belediyeler arasında da dengesizlikler oluşturmaktadır. Belirtmek gerekir ki, kanunda belirlendiği şekilde nüfus dilimleriyle temsilci sayısı arasında kurulan ilişki, büyükşehir ilçe belediyeleri dışındaki belediyeler için herhangi bir sorun teşkil etmemektedir. Ancak bu düzenleme, mevcut haliyle büyükşehir ilçe belediyeleri için de uygulanmaya başlandığında sorun çıkmaktadır. Çünkü bu düzenleme, büyükşehir ilçe belediyelerinin büyükşehir belediye meclisindeki temsilinde, temsil adaletsizliğine yol açmaktadır. Büyükşehir ilçe belediyeleri arasındaki nüfus farklılıklarının artmasına paralel olarak temsil adaletsizliği de artmaktadır (Arıkboğa, 2009:741).

Büyükşehirlerdeki temsil adaletsizliği sorununun iyi değerlendirilebilmesi için Kahramanmaraş'1n büyükşehir olmadan önceki durumuna bakmak gerekmektedir. Tablo 9'a göre; 6360 sayılı Kanun öncesi temsil ve katılım açısından Kahramanmaraş genelinde ortalama 1390 kişiyi bir meclis üyesi temsil etmektedir. Belde belediyelerinin büyük çoğunluğu Kahramanmaraş ortalamasının altındadır. Bu temsil ve katılım açısından olumlu görülmektedir. Ancak nüfus arttıkça temsil oranının düştüğü görülmektedir. Özellikle ilçe belediyeleri temsil ortalamaları Kahramanmaraş ilinin genel temsil ortalamasının çok üzerindedir. Bu da ilçe ve belde belediyeleri arasında bir temsil adaletsizliği olduğunu ortaya koymaktadır. Özellikle Kahramanmaraş il belediyesindeki duruma bakılırsa 11.988 kişiye bir meclis üyesi düşmektedir. Bununla birlikte Afşin, Göksun, Elbistan ve Pazarcık ilçeleri ortalama temsil miktarı olarak belirlenen 1390 'nın üzerindedir.

Tablo 9. Kahramanmaraș İlinde Belediye Meclis Üye Sayıları ve Temsil

\begin{tabular}{|l|l|l|l|l|l|l|l|l|l|}
\hline İlçe & Belediye & Nüfus & $\begin{array}{l}\text { Belediye } \\
\text { Meclisi } \\
\text { Üye } \\
\text { Sayisı }\end{array}$ & $\begin{array}{l}\text { Ortalama } \\
\text { Temsil } \\
\text { Nüfus/Bel } \\
\text { ediye } \\
\text { Meclis } \\
\text { Unye } \\
\text { Sayisı) }\end{array}$ & İlce & Belediye & Nüfus & $\begin{array}{l}\text { Belediy } \\
\text { e } \\
\text { Meclisi } \\
\text { Uyye } \\
\text { Sayisı }\end{array}$ & $\begin{array}{l}\text { Ortalama } \\
\text { Temsil(Nüf } \\
\text { us/Belediye } \\
\text { Meclis Üye } \\
\text { Sayisı) }\end{array}$ \\
\hline $\begin{array}{l}\text { Tüm } \\
\text { Belediyele }\end{array}$ & $\begin{array}{l}\text { Tüm } \\
\text { Belediyele }\end{array}$ & 861.922 & 620 & 1390 & Elbistan & Elbistan & 95.037 & 25 & 3801 \\
\hline
\end{tabular}




\begin{tabular}{|c|c|c|c|c|c|c|c|c|c|}
\hline$r$ & $\mathrm{r}$ & & & & & & & & \\
\hline \multirow[t]{12}{*}{ Merkez } & $\begin{array}{l}\text { Kahraman } \\
\text { maraş }\end{array}$ & 443,575 & 37 & 11.988 & & & & & \\
\hline & Baydemirli & 3.362 & 9 & 373 & & Akbayır & 1.414 & 9 & 157 \\
\hline & Döngele & 2.370 & 9 & 263 & & Bakış & 1.786 & 9 & 198 \\
\hline & Fatih & 4.977 & 9 & 553 & & $\begin{array}{l}\text { Büyükyap } \\
\text { alak }\end{array}$ & 2.502 & 9 & 278 \\
\hline & Fatmali & 3,894 & 9 & 432 & & Demircilik & 1.849 & 9 & 205 \\
\hline & Ilica & 2.607 & 9 & 289 & & Doğan & 2.845 & 9 & 316 \\
\hline & Kale & 4.093 & 9 & 454 & & Izgin & 2.308 & 9 & 256 \\
\hline & Karadere & 1.298 & 9 & 144 & & İğde & 2.233 & 9 & 248 \\
\hline & Kürtül & 2.529 & 9 & 281 & & $\begin{array}{l}\text { Karaelbist } \\
\text { an }\end{array}$ & 6.012 & 9 & 668 \\
\hline & Önsen & 4.150 & 9 & 461 & & Söğütlü & 2.350 & 9 & 261 \\
\hline & $\begin{array}{l}\text { Şahinkaya } \\
\text { S1 }\end{array}$ & 2,941 & 9 & 326 & Göksun & Göksun & 18.775 & 11 & 1706 \\
\hline & Tekir & 3.462 & 9 & 384 & & Bozhüyük & 1.260 & 9 & 140 \\
\hline \multirow{11}{*}{ Afşin } & Afşsin & 43.217 & 15 & 2881 & & $\begin{array}{l}\text { Büyükkızıl } \\
\text { cık }\end{array}$ & 5.041 & 9 & 560 \\
\hline & Alemdar & 834 & 9 & 92 & & Çardak & 1.748 & 9 & 194 \\
\hline & Altınelma & 2528 & 9 & 280 & & $\begin{array}{l}\text { Değirmend } \\
\text { ere }\end{array}$ & 1.909 & 9 & 212 \\
\hline & Arıtaş & 5,359 & 9 & 595 & & Ericek & 2.998 & 9 & 333 \\
\hline & Bakraç & 1.368 & 9 & 152 & & $\begin{array}{l}\text { Kanlıkava } \\
\text { k }\end{array}$ & 1.937 & 9 & 215 \\
\hline & Büyüktatlı & 1.416 & 9 & 157 & & Taşoluk & 1.314 & 9 & 146 \\
\hline & $\begin{array}{l}\text { Çobanbeyl } \\
\mathrm{i}\end{array}$ & 3.244 & 9 & 360 & \multirow[t]{4}{*}{ Nurhak } & Nurhak & 5.611 & 9 & 623 \\
\hline & Çoğulhan & 2.058 & 9 & 228 & & Barış & 2.202 & 9 & 244 \\
\hline & Dağlica & 1.104 & 9 & 122 & & Kullar & 2.628 & 9 & 292 \\
\hline & Esence & 770 & 9 & 85 & & Tatlar & 2.766 & 9 & 307 \\
\hline & Tanır & 2.454 & 9 & 272 & \multirow[t]{5}{*}{ Pazarcık } & Pazarcık & 28.797 & 15 & 1919 \\
\hline \multirow[t]{3}{*}{ Andırın } & Andırın & 7.989 & 9 & 887 & & $\begin{array}{l}\text { Büyüknaca } \\
\text { r }\end{array}$ & 2.129 & 9 & 236 \\
\hline & Geben & 1,890 & 9 & 3612 & & Evri & 2.452 & 9 & 272 \\
\hline & Yeşilova & 2.360 & 9 & 262 & & Narlı & 7.460 & 9 & 828 \\
\hline \multirow[t]{3}{*}{$\begin{array}{l}\text { Çağlayanc } \\
\text { erit }\end{array}$} & $\begin{array}{l}\text { Çağlayanc } \\
\text { erit }\end{array}$ & 12.088 & 11 & 1098 & & $\begin{array}{l}\text { Yumaklice } \\
\text { rit }\end{array}$ & 2.294 & 9 & 254 \\
\hline & Bozlar & 1,993 & 9 & 221 & \multirow[t]{5}{*}{ Türkoğlu } & Türkoğlu & 15.262 & 11 & 1387 \\
\hline & Helete & 5.536 & 9 & 615 & & Beyoğlu & 8.183 & 9 & 909 \\
\hline Ekinözü & Ekinözü & 5.238 & 9 & 582 & & Kil111 & 6.222 & 9 & 691 \\
\hline \multirow[t]{2}{*}{ 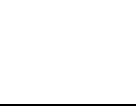 } & & & & & & Şekeroba & 7.460 & 9 & 828 \\
\hline & & & & & & Yeşilyöre & 3.815 & 9 & 423 \\
\hline
\end{tabular}

Kaynak: TUIK, 2012

6360 sayılı Kanun sonrası duruma bakıldı̆̆ında ilçe belediye meclisi ortalama temsili artarak 4285 olmuştur. Dulkadiroğlu Büyükşehir İlçe Belediyesinde 6990 kişiye bir belediye meclis üyesi, Onikişubat büyükşehir ilçe belediyesinde 9672 kişiye bir meclis üyesi düşmektedir. Bu sayı ortalama temsil miktarı olan 
4285'in çok üzerindedir. Bu da 6360 sayılı Kanun'un Kahramanmaraş il merkezinde oluşturulan ilçelerin aleyhine bir durum oluşturmaktadır. Büyükşehir belediye meclisindeki duruma baktığımızda aynı durumun devam ettiğini bununla birlikte az nüfuslu belediyelerin temsil açısından avantajlı olduğu görülmektedir. Örneğin Ekinözü ilçesi 13.461 nüfusa sahip iken 3 temsilci göndermekte, Dulkadiroğlu İlçesi 216.701 nüfusa sahip iken 7 temsilci göndermektedir. Bununla birlikte Ekinözü ilçesinin büyükşehir belediye meclisindeki ortalama temsil oran1 4487 kişi iken Dulkadiroğlu İlçesinin ise $30.975^{\prime}$ dir. Büyükşehir belediye meclislerinin az nüfuslu belediyeler lehine oluşturulması, kalabalık ilçelerin isteklerinin büyükşehir belediye meclisine ulaşmasını güçleştirecektir. Ancak diğer bir açıdan bakıldığında ise nüfusu az olan ilçelerde meclis üye sayısı da az olmaktadır. Bu nedenle Andırın, Ekinözü ve Nurhak ilçelerinin büyükşsehir belediye meclis üye sayısı diğerlerine göre çok daha az olmaktadır. Bu dağılım büyükşehir belediye hizmetlerinin dağılımını da etkileyebilir. Bu anlamda 6360 sayılı Kanun öncesi ve sonrasında Kahramanmaraş'ta temsil açısından olumlu bir gelişme olduğu söylenemez. Ancak belde belediyeleri kapatılmamış olsaydı temsil adaletsizliği çok fazla olacak ve büyükş̧ehirler açısından aşılamayacak sorunlar oluşabilecekti. Bu açıdan belde belediyelerinin kapatılması büyükşehir belediye meclisindeki temsile olumlu yansımıştır. Sonuç olarak Kahramanmaraş'ta Büyükşehir Belediye Kanunu'ndan sonra ilçe belediyelerinde meclis üye sayıs1 251, büyükşehir belediye meclis üye sayısı ise 60 olmuştur (Tablo 10).

Tablo 10. Kahramanmaraş İlinde 2014 Yerel Seçimleri Sonrası Belediye Meclis Üye Sayıları ve Temsil

\begin{tabular}{|c|c|c|c|c|c|}
\hline İlçe & Nüfus & $\begin{array}{l}\text { Belediye } \\
\text { Meclis Üye } \\
\text { Sayısı }\end{array}$ & $\begin{array}{l}\text { İlçe Belediye Meclisi } \\
\text { Ortalama } \\
\text { temsil(Nüfus/Belediye } \\
\text { Meclis Üye Sayısı) }\end{array}$ & $\begin{array}{l}\text { Büyükssehir } \\
\text { Belediye } \\
\text { Meclisine } \\
\text { Gönderilen } \\
\text { Üye Sayısı } \\
\end{array}$ & $\begin{array}{lc}\text { Büyükșehir } & \text { Belediye } \\
\text { Meclisi } & \text { Ortalama } \\
\text { Temsil(Nüfus/BŞB } \\
\text { Meclisine } \\
\text { Üye Sayınderilen } \\
\end{array}$ \\
\hline Afşsin & 82.662 & 25 & 3306 & 6 & 13.777 \\
\hline Andırın & 35.943 & 15 & 2396 & 4 & 8.985 \\
\hline Çağlayancerit & 25.276 & 15 & 1685 & 4 & 6.319 \\
\hline Dulkadiroğlu & 216.701 & 31 & 6990 & 7 & 30.975 \\
\hline Ekinözü & 13.461 & 11 & 1223 & 3 & 4.487 \\
\hline Elbistan & 140.493 & 31 & 4532 & 7 & 20.070 \\
\hline Göksun & 53.157 & 25 & 2126 & 6 & 8.859 \\
\hline Nurhak & 13.414 & 11 & 1219 & 3 & 4.471 \\
\hline Onikişubat & 357.870 & 37 & 9672 & 8 & 44.733 \\
\hline Pazarcık & 68.843 & 25 & 2753 & 6 & 11.473 \\
\hline Türkoğlu & 67.886 & 25 & 2715 & 6 & 11.314 \\
\hline Toplam & 1.075 .706 & 251 & 4285 & 60 & 17.928 \\
\hline
\end{tabular}

Kaynak: TUİK, 2013

Büyükşehir Belediye Kanunu'ndan önce Kahramanmaraş’taki 62 belediyenin toplam 620 belediye meclis üyesi ve 41 il genel meclis üyesi vardı (Tablo 9, 10 ve 11). Büyükşehir Belediye Kanunu'ndan önce Kahramanmaraş'ta kırsal alanlara hizmetler il genel meclisi aracılığı ile yapılmaktaydı. Yeni Kanun ile birlikte il genel meclisi kaldırıldı ve yerine büyükşehir belediye meclisi getirilmiştir. Bu değişimle birlikte ilçeler arasındaki il genel meclisi ile büyükşehir belediye meclis oranı değişmiştir. Özellikle kırsal nüfusu fazla olan ilçelerde büyükşehir belediye meclis üye sayısı artmıştır. Kahramanmaraş ili il genel meclis üye sayısı toplamı 41 olup, merkez ilçenin oranı \%22 iken, büyükşehir belediye meclis üye sayısı oran1 \%24 olarak ağırlı̆̆ 1 artmıştır. Kuzey ilçelerinin (Afşin, Ekinözü, Elbistan, Nurhak) İl genel meclis üye oranı \%44 iken, büyükşehir belediye meclis üye oran $\% 40$ 'a düşmüştür. Bu oransal değişiklik kuzey ilçelerinin il genel meclisine göre büyükşehir belediye meclisindeki ağırlığı azalacaktır. 
Tablo 11. Kahramanmaraş'ta Büyükşehir Belediye Kanunu'ndan Sonra Belediye Meclis Üye Sayısı, 2014

\begin{tabular}{|l|c|c|c|}
\hline Kahramanmaraş & İlçe Meclis Üyesi & BŞB Meclis Üyesi & İ Genel Meclis Üyesi \\
\hline Afşin & 25 & 6 & 5 \\
\hline Andırın & 15 & 4 & 3 \\
\hline Çağlayancerit & 15 & 4 & 3 \\
\hline Dulkadiroğlu & 31 & 7 & $9^{1}$ \\
\hline Ekinözü & 11 & 8 & 5 \\
\hline Elbistan & 31 & 7 & 4 \\
\hline Göksun & 25 & 6 & 2 \\
\hline Nurhak & 11 & 3 & 4 \\
\hline Onikişubat & 37 & 8 & 4 \\
\hline Pazarcık & 25 & 6 & 6 \\
\hline Türkoğlu & 251 & 60 & 4 \\
\hline Toplam & & 6 & 4 \\
\hline
\end{tabular}

Kaynak: Türkiye Belediyeler Birliği

6360 sayılı Kanun ile birlikte idari sistemde meydana getirilen birleşmeler ve mücavir alan sınırlarının genişlemesi, seçim çevrelerinde de değişikliğe neden olmuştur. Kahramanmaraş açısından bakıldığında 6360 sayılı Kanun öncesinde 2009 yerel seçim sonuçlarına göre 9 ilçenin 6's1 AK Parti belediyesi iken 2 belediye CHP ve 1 belediye MHP belediyesi idi. 30 Mart 2014 seçim sonuçlarına göre ise bu 9 ilçe belediyesinin 8'i AK Parti belediyesi iken sadece 1 tanesi CHP belediyesi olmuştur. Eğer seçim sonuçlarını 6360 sayılı Kanun'un seçim çevrelerinde meydana getirdiği değişimi değerlendirerek açıklanırsa; köy ve beldelerin ilçe belediye seçimlerinde oy kullanmaları bu değişimin temel nedenlerinden biri olabilir.

\subsection{MALI YAPI (BÜTÇELER) AÇISINDAN MEYDANA GELEN DEĞİşiKLIKKLER}

Türkiye'de yerel düzeyde kamu hizmetleri belediyeler tarafindan sunulmaktadır. Belediyeler bu hizmetleri yerine getirebilmesi için yeterli bir bütçeye ihtiyacı vardır. Bu bütçe genel vergi gelirleri ve kendilerinin ürettiği yerel öz kaynaklardan sağlanmaktadır. Bu nedenle günümüzde belediyelerin imkânlar ölçüsünde mali ve dolayısıyla idari özerkliğinin sağlanması görüşü, yaygın olarak benimsenmiştir (Demircan, 2008: 108). Ancak Türkiye'de belediyelerin gelir dağılımına bakıldığında gelirlerin büyük çoğunluğu genel bütçe vergi gelirlerinden oluştuğu görülmektedir (Şekil 10). Nitekim mali özerklik açısından genel bütçe vergi gelirlerine bağımlı olmayan bir yerel yönetim sistemi oluşturulursa ülkemizde yerelleşme olgusu adına önemli bir adım atılmış olacaktır.

\footnotetext{
${ }^{1}$ Dulkadiroğlu ve Onikişubat ilçeleri Merkez ilçe olarak birlikte il genel meclis üye sayısı
} 


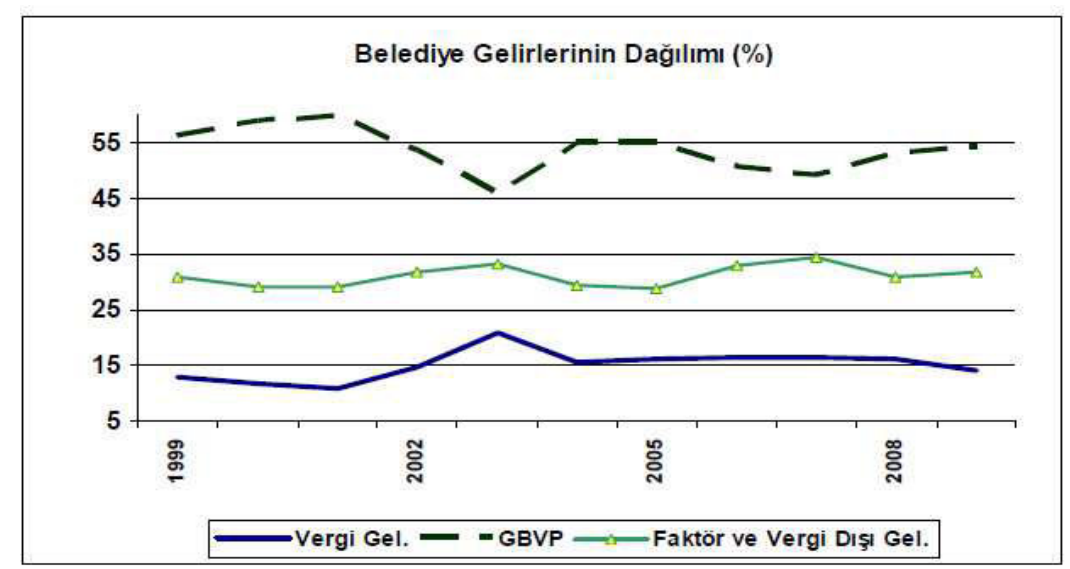

Şekil 10. Belediye Gelirlerinin Dağılımı (Usta, 2010: 6).

6360 sayılı Kanun öncesi uygulamaya göre, yerel yönetimlerin finansmanı için genel bütçe vergi gelirlerinden çeşitli paylar aktarılmaktaydı. Konuya ilişkin Kanun'da bu oran şöyle belirlenmiştir: Genel bütçe vergi gelirleri (GBVG) tahsilâtı toplamının; \%2,85'i büyükşehir dışındaki belediyelere, \%2,50'si büyükşsehir ilçe belediyelerine ve \%1,15'i il özel idarelerine ayrılır. Büyükşehir belediye sınırları içinde yapılan genel bütçe vergi gelirleri tahsilâtı toplamının \%5'i ile genel bütçe vergi gelirleri tahsilâtı toplamı üzerinden büyükşehir ilçe belediyelerine ayrılan payların \%30'u büyükşehir belediye payı olarak ayrılır. Buradaki ölçüt ise her yılın Ocak ayından geçerli olmak üzere o sınırlar içinde yaşayan nüfustur.

6360 sayılı Kanun ile belediyelerin vergi gelirleri, faktör ve vergi dışı gelirleri konusunda herhangi bir değişikliğe gidilmemiş olup, genel bütçe gelirlerinden ayrılan payların oranı değişmiştir. Buna göre; 5779 sayılı Kanun'un 5. maddesinin ikinci, üçüncü ve dördüncü fikraları değiştirilerek, büyükşehir ilçe belediyelerinin genel bütçe vergi gelirlerinden aldığg pay 2 puanlık bir artışla $\% 4,5$ 'e çıkmış olup, büyükşehir belediyelerine ayrılan pay ise \%5'den \%6'ya çıkmıştır. Bununla birlikte büyükşehirlerdeki ilçe belediyeleri payının; \%90'lık kısmı ilçelerin nüfusuna, \%10’luk kısmı ise ilçelerin yüzölçümüne göre dağıtılması öngörülerek, hesaplanan tutardan \%30'luk büyükşsehir belediyesi payı ayrıldıktan sonra kalan miktar büyükşehir ilçe belediyelerinin hesabına İlbank A.Ş. tarafindan aktarılacaktır. Büyükşehir belediyelerinde ise ayrılan \%6'lık büyükşehir belediye payının \%60'1 doğrudan ilgili büyükşehir belediyesi hesabına aktarılacak olup, kalan \%40'l1k kısmının \%70'i nüfusa, \%30’u yüzölçümü esasına göre büyükşehir belediyeleri arasında dağıtılacaktır. (6360 sayılı Kanun Md. 25-26)

Tablo 12. Genel Bütçe Vergi Gelirlerinin Yerel Yönetimlere Dağılım Oranlar|
\begin{tabular}{|l|c|c|}
\hline Yerel Yönetim Türü & $\begin{array}{l}\mathbf{5 7 7 9} \text { Sayılı Kanun İle } \\
\text { Uygulanan Oranlar (\%) }\end{array}$ & $\begin{array}{l}\mathbf{6 3 6 0} \text { Sayll Kanun İle } \\
\text { Öngörülen Oranlar (\%) }\end{array}$ \\
\hline İl özel idareleri & 1.15 & 0.5 \\
\hline İl, ilçe ve belde belediyeleri & 2.85 & 1.50 \\
\hline Büyükşehir ilçe belediyeleri & 2.50 & 4.50 \\
\hline Büyükșehir belediyeleri & 5 & 6 \\
\hline
\end{tabular}

Güngör'ün (2013) verdiği bilgilere göre; mevcut durumda 2011 yılı verilerine göre yerel yönetimlere genel bütçe vergi gelirlerinden yaklaşık \%10,30 pay aktarılmaktadır. Bunun rakamsal değeri ise 25.576.247.306 TL olup kişi baş1 342 TL düşmektedir. 6360 sayılı Kanun ile genel bütçeden yerel yönetimlere aktarılan pay oranı yaklaşık \%11,38 çıkmaktadır. Bunun ise 2011 yılı verilerine göre parasal değeri 28.309.547.316 TL olup kişi başına 379 TL düşmektedir. 6360 sayılı Kanun ile 5779 sayılı Kanun'da yapılan değişiklik ile yerel yönetimlere genel bütçeden aktarılan paylarda yaklaşık \% 10,5 'lik bir artış sağlanmaktadır (Güngör, 2013). 
Yukarıda belirtilen değişiklikler dikkate alınarak Türkiye Ekonomi Politikaları Araştırma Vakfı (TEPAV) tarafindan yapılan bir analizde; eğer 2011 yılı bütçe verilerine göre Kahramanmaraş büyükşehir olsaydı, 6360 sayılı Kanun öncesi ve sonrası belediyelerin genel bütçe gelirlerinden alacağ payların artış oranının ne olacağı Tablo 13'de ortaya konulmuştur. Bu araştırma sonucuna göre genel bütçe vergi gelirleri oranı azalan ilçeler sırasıyla; Elbistan, Çağlayancerit ve Afşin'dir. GBVG transfer payı artış oranı en yüksek olan ilçe ise \%97 ile Andırın'dır. Andırın'ı sırasıyla Türkoğlu, Nurhak, Göksun, Pazarcık ve Ekinözü takip etmektedir. Bu veriler dikkate alınarak değerlendirme yapılırsa Kahramanmaraş'ın nüfus ve yüzölçümü açısından en büyük ilçelerinden biri olan Elbistan'ın genel bütçe gelirlerinden ayrılan pay oranının düşmesi ilçede hizmet sunumunda çeşitli sorunlara neden olacaktır. Bu kapsamda değişen oranların dikkate alınarak hesaplama sisteminde değişikliğe gidilmesi yararlı olacaktır.

Tablo 13. Kahramanmaraş İlçe Belediyeleri 6360 Sayılı Kanun Öncesi ve Sonrası Genel Bütçe Vergi Gelirlerinden Transfer Edilen Pay

\begin{tabular}{|c|c|c|c|c|c|c|c|c|c|c|c|}
\hline Belediye & $\begin{array}{l}\text { Nüfus } \\
\text { (Bld) }\end{array}$ & \begin{tabular}{|l} 
Yüzölç \\
üm \\
$(\mathrm{Km} 2)$
\end{tabular} & \begin{tabular}{|l} 
SEGE \\
'ye \\
Göre \\
Dağitil \\
an \\
Pay
\end{tabular} & $\begin{array}{l}\text { Nüfusa } \\
\text { Göre Pay } \\
\text { (Bin Tl, } \\
\text { Diğer } \\
\text { Bldler } \\
\text { Için \%80 }\end{array}$ & $\begin{array}{l}\text { BŞB Ilçe } \\
\text { Yüzölçüm } \\
\text { e Göre } \\
\text { Pay (\% 10, } \\
\text { Bin Tl) } \\
{[C]}\end{array}$ & $\begin{array}{l}\text { BŞB } \\
\text { Ilçelerden } \\
\text { BŞB'lere } \\
\text { Ayrilan } \\
\text { Pay } \\
\text { Bin }\end{array}$ & $\begin{array}{l}\text { BŞB } \\
\text { Ilçelerde } \\
\text { n Sk } \\
\text { Idareleri } \\
\text { ne } \\
\text { Ayrilan }\end{array}$ & $\begin{array}{l}\text { Denkleşti } \\
\text { rme } \\
\text { Ödeneği } \\
\text { (Bin Tl) } \\
{[\mathrm{F}]}\end{array}$ & $\begin{array}{l}\text { Toplam } \\
\text { GBVG } \\
\text { Transfer } \\
\text { Payi (Yeni } \\
\text { Kanun, } \\
\text { Bin Tl) }\end{array}$ & $\begin{array}{l}\text { Toplam } \\
\text { GBVG } \\
\text { Transfer } \\
\text { Payi } \\
\text { (Mevcut } \\
\text { Sistem, }\end{array}$ & $\begin{array}{l}\text { Artiş } \\
\text { Yüzde } \\
\text { si }\end{array}$ \\
\hline Afşsin & 84244 & 1434 & 0 & 15317 & 4169 & 5846 & 1949 & 0 & 11 , & 12,889 & $-9 \%$ \\
\hline Andırın & 38074 & 1198 & 0 & 6923 & 3483 & 3122 & 1041 & 0 & 6,243 & 3,167 & $97 \%$ \\
\hline Cagliyancerit & 26257 & 419 & 0 & 4774 & 1218 & 1798 & 599 & 0 & 3,595 & 4,443 & $-19 \%$ \\
\hline Ekinözu & 14363 & 598 & 0 & 2611 & 1739 & 1305 & 435 & 0 & 2.610 & 2.259 & $16 \%$ \\
\hline Elbistan & 139046 & 2328 & 0 & 25281 & 6769 & 9615 & 3205 & 0 & 19 & 23,861 & $-19 \%$ \\
\hline Göksun & 54024 & 1949 & 0 & 9823 & 5667 & 4647 & 1549 & 0 & 9.294 & 6.324 & $47 \%$ \\
\hline Nurhak & 14099 & 1225 & 0 & 2563 & 3562 & 1838 & 613 & 0 & 3.675 & 2.176 & $69 \%$ \\
\hline Pazarcık & 73227 & 1739 & 0 & 13314 & 5056 & 5511 & 1837 & 0 & 11, & 9,512 & $16 \%$ \\
\hline Türkoğlu & 65172 & 603 & 0 & 11850 & 1753 & 4081 & 1360 & 0 & 8.162 & 4.816 & $69^{\circ}$ \\
\hline
\end{tabular}

Kaynak: TEPAV, www. tepav.org. tr. E.T. 10.03.2014

Tablo 14. Kahramanmaraş Büyükşehir Belediyesine 6360 Sayılı Kanun Öncesi ve Sonrası Genel Bütçe Vergi Gelirlerinden Transfer Edilen Pay

\begin{tabular}{|l|l|l|l|l|l|}
\hline $\begin{array}{l}\text { Mevcut Yerel } \\
\text { Yönetim } \\
\text { Payı(Bin TL) }\end{array}$ & $\begin{array}{l}\text { Yeni Yerel Yönetim } \\
\text { Payı(Bin TL) }\end{array}$ & $\begin{array}{l}\text { Mevcut Kişi } \\
\text { Başı(TL) }\end{array}$ & Yeni Kişi Başı (TL) & Artış Yüzdesi(Pay) & $\begin{array}{l}\text { Artış Yüzdesi(Kişi } \\
\text { Başı) }\end{array}$ \\
\hline 269482 & 367559 & 256 & 349 & 36,4 & 93 \\
\hline
\end{tabular}

Kaynak: Koyuncu, 2012: 10

Kahramanmaraş büyükşehir belediyesinin gelirlerinde nasıl bir değişim olacağına bakıldığında yerel yönetim payının 6360 sayılı Kanun öncesinde \%36,4 arttığını, kişi başı artış yüzdesinin ise \%93 olduğu görülüyor. Bu sonuçlara göre Kahramanmaraş ili eski sisteme göre daha fazla pay alarak hizmet sunumunu daha hızlı ve etkin bir şekilde yerine getirebilir.

Türkiye Belediyeler Birliği tarafından yapılan başka bir araştırma ise Kahramanmaraş belediyelerinin bütçe açısından eski ve yeni sistemde ne gibi değişime uğradığını göstermektedir. Büyükşehir belediyesi sınırlarında ikamet eden bir kişiye düşen pay bakımından Kahramanmaraş olumlu etkilenmektedir. Bu durumda mevcut yerel yönetim pay1 273.516.027 TL iken bu pay 374.049.294 TL'ye çıkacaktır. Kişi başına düşen pay ise 259 TL'den 352 TL'ye çıkmaktadır (Tablo 15). Fakat ilçe belediyeleri açısından değerlendirildiğinde ise kişi başına düşen pay azalmaktadır. Çünkü daha önceki ilçe belediyeleri sadece ilçelerin merkezindeki şehir nüfusuna hizmet verirken, yeni kanun ile beraber tüm ilçe nüfusuna hizmet verecektir.

Tablo15. Kahramanmaraș'ın Belediyelerinde Pay Dağılımı 


\begin{tabular}{|c|c|c|c|c|c|c|}
\hline Kahramanmaraş & Şehir Nüfusu & $\begin{array}{c}\text { Toplam } \\
\text { TL }\end{array}$ & Kişi Başı TL & Toplam Nüfus & $\begin{array}{c}\text { Toplam Pay } \\
\text { TL }\end{array}$ & Kişi Başı TL \\
\hline Büyükşehir belediyesi & - & - & - & 1.063 .174 & 218.530 .934 & 206 \\
\hline Su ve kan. İdaresi & - & - & - & 1.063 .174 & 22.060 .622 & 21 \\
\hline İl belediyesi & 428.724 & 100.995 .929 & 236 & - & - & - \\
\hline Afşsin & 42.296 & 13.556 .417 & 321 & 83.016 & $10.420 .804 \mathrm{TL}$ & 126 \\
\hline Andırın & 7.845 & 2.997 .914 & 382 & 36.129 & 4.535 .189 & 126 \\
\hline Çağlayancerit & 12.218 & 4.669 .027 & 382 & 25.382 & 3.186 .143 & 126 \\
\hline Dulkadiroğlu & - & - & - & 217.356 & 27.284 .189 & 126 \\
\hline Ekinözü & 5.349 & 2.044 .084 & 382 & 13.523 & 1.697 .510 & 126 \\
\hline Elbistan & 92.386 & 25.054 .304 & 271 & 139.545 & 17.516 .757 & 126 \\
\hline Göksun & 19.090 & 6.641 .020 & 348 & 52.535 & 6.594 .595 & 126 \\
\hline Nurhak & 5.620 & 1.955 .083 & 348 & 13.396 & 1.681 .568 & 126 \\
\hline Onikişubat & - & - & - & 343.786 & 43.154 .650 & 126 \\
\hline Pazarcık & 28.716 & 9.989 .709 & 348 & 71.346 & 8.955 .896 & 126 \\
\hline Türkoğlu & 14.539 & $5.057 .820 \mathrm{TL}$ & 348 & 67.160 & 8.430 .437 & 126 \\
\hline Belde belediyeleri & 159.485 & 47.195 .251 & 296 & - & - & - \\
\hline Bel toplam / ortalama & 816.268 & 220.156 .558 & 270 & 1.063 .174 & 374.049 .294 & 352 \\
\hline İl özel idareleri & 1.054 .210 & 53.359 .469 & 51 & - & - & - \\
\hline Toplam - Ortalama & 1.054 .210 & 273.516 .027 & 259 & - & - & - \\
\hline
\end{tabular}

Kaynak: Türkiye Belediyeler Birliği

Öte yandan DPT tarafindan 2006 yılında Türkiye'deki belediyelerin gelir ve harcama yapıları üzerine yapılan bir araştırmada (Kurtuluş, 2006), belediyelerin asgari büyüklüğü ile hizmet etkinliği ve maliyeti arasındaki ilişkiyi doğrulayan bulgular mevcuttur. Örneğin nüfusu 10000'in altında olan belediyelerde kişi başına personel harcamalarının oranı \%34,8 ile diğer belediyelerden daha fazla çıkmıştır. Benzer şekilde 5 binin altındaki belediyelerde bu oran \%41,8'e ulaşmaktadır. Buna karşıllı belediye personeli başına, düşen yurttaş sayısı küçük belediyelerde daha azdır. Başka bir ifadeyle, büyük belediyelerdeki çalışanlara kıyasla küçük belediyelerdeki bir personelin iş yükü daha az iken, personel ödemelerinin belediye bütçesi içindeki oranı daha yüksek düzeyde gerçekleşmektedir. Yine 5 bin nüfusun altındaki belediyelerde idari harcamaların oranı diğer belediyelere kıyasla çok daha yüksek düzeydedir (Kurtuluş, 2006: 86-94'den akt. Arıkboğa, 2008: 301). Araştırmada elde edilen sonuçlar personel harcamaları açısından 6360 sayılı Kanun ile Kahramanmaraş'ta belde belediyelerin bütçe açısından(nüfusu 10 binin üzerinde belde belediyesi bulunmamaktadır) kapatılması kararının yerinde olduğunu göstermektedir.

\section{SONUÇ}

Türkiye'de şehirlerin nüfus ve mekânsal alan olarak büyümesi, ihtiyaçların çeşitlenmesi, toplumun belediyelerden hizmet beklentilerinin artması vb. nedenlerle belediye teşkilatlarında yeni düzenlemeler yapma ihtiyacı doğmuştur. Bu gelişmelerin sonucunda, 1982 Anayasa'sında büyük yerleşim birimleri için özel yönetim birimleri kurulabilir hükmü getirilmiş ve bu hükme dayanılarak ilk defa 1984 yılında çıkarılan 3030 sayılı Kanun ile büyükşehir belediyesi kurulmuştur. Daha sonra büyükşehir belediyelerine ilişkin 2004 yılında 5216 Sayılı ve 2012 yılında 6360 sayılı Kanun çıkarılmıştır. Büyükşsehir belediye kanunlarında yapılan değişiklikler analiz edildiğinde, belediye kurma kriterlerinin bilimsel veri ve teorilerin yanında siyasi kararlardan da etkilendiği görülmektedir. Günümüzdeki büyükşehir kanunu ile büyükşehir belediye il mülki idare sınırlarının tamamına hizmet verir hale getirilmiştir. Bu değişiklik belediye yönetim anlayışında bir ezberi bozmuş ve merkez (şehir) yönetiminden mekânsal alan yönetimine geçilmiştir. Bu durum belediye hizmetlerinin şehir nüfusu yanında kırsal nüfusa da ulaştırılması anlamına gelmektedir. 6360 sayılı Kanun'daki yeni modelde büyükşehir belediyesinin uygulama alanı il ölçeğidir. Bu model sadece bir büyükşehir belediye modeli olmayıp büyükşehir belediye, belediye, köy ve il özel idaresinin bütünleştirileceği bir yerel yönetim yapısı getirmektedir. Yani belediyeler sadece şehirleri değil ilin mülki idare sınırlarından oluşan büyük bir mekânı yönetecektir.

6360 sayılı Kanuna göre, tüm il sınırlarının büyükşehir belediye sınırı olarak kabul edilmesi, köylerin, bucakların ve belde belediyelerinin kapatılarak mahalle statüsüne dönüştürülmesi, il özel idarelerinin kapatılarak belediyelere devredilmesine ilişkin hükümler bulunmaktadır. Kanun gerekçesinde hizmet sunumu bakımından daha etkili ve verimli bir yönetsel yapının inşa edileceği, bu yapının demokratik hayata katılımı sağlayacağı, geniş ölçekli planlama politikalarının uygulanacağı, imar bütünlüğünün 
sağlanacağı, nitelikli teknik personelin istihdam edilmesi ile verimliliğin artması, etkin kaynak kullanımı ve bölüşümünün sağlanacağı ifade edilmektedir.

Büyükşehir alanında sunulan hizmetlerin tek merkezden yürütülmesi ile ortaya çıkan ölçek ekonomileri sayesinde; hizmetlerde etkinlik, koordinasyon ve kalite yükselecek, daha az kaynak ile daha çok ve daha kaliteli hizmet sunulması mümkün hale gelebilecektir. Hâlihazırda birden fazla merkezden verilen hizmetlerin daha büyük ve ideal ölçekteki bir merkez tarafından verilmesi birim maliyetler ve kişi başına kamusal harcamaları da azaltacaktır. Kahramanmaraş ilinin büyükşehir yapılması ile ölçek ekonomileri oluşturularak hizmetin etkin ve verimli sunulması yolu ile hizmet maliyetlerinin düşürülmesi öngörülmektedir. Bu bakımdan belde belediyelerinin kapatılarak mahalleye dönüștürülmesi hizmet maliyeti ve nüfus ilişkisi açısından olumlu yansıyacaktır. Ancak il merkezine $200 \mathrm{~km}$ uzaklıkta, merkezden yüksek ve sıradağlarla ayrılmış ilin kuzey bölgelerine büyükşehir belediyesinin hizmet sunmasında zorluklar yaşanacağını vurgulamak gerekir. Nitekim Kahramanmaraş ilindeki belde belediyelerinin ve köylerin ilçe ve iller arası uzaklıkları hizmet maliyetine ek olarak ulaşım maliyetlerinin eklenmesine de neden olacaktır. Belirli mesafeden sonra hizmetlerin birim maliyeti artacağı için büyükşehir belediyeleri buralara hizmet götürme de gönülsüz veya eşitsiz davranabilir. Özellikle nüfus yoğunluğunun az olduğu Nurhak ve Ekinözü gibi ilçeler ulaşım maliyetinin olumsuz yansımaları ile karşı karşıya kalacaktır. Bu bölgeler için farklı hizmet modelleri ve birimleri oluşturularak maliyetlerin düşürülmesi sağlanabilir. Bununla birlikte kalabalık olan ilçelere eklenecek kalabalıklaşma maliyeti bu bölgelerin hizmet maliyetine olumsuz olarak yansıyacaktır. Büyükşehir ilçe belediyeleri için bir alt sınır belirlenmiş ancak bir üst sınırın olmaması hizmetten sağlanan faydanın azalmasına ve maliyetlerin artmasına neden olabilir. Bu maliyet artışından Kahramanmaraş merkez ilçenin bölünmesi ile oluşturulan Dulkadiroğlu ve Onikişubat ilçelerinin etkileneceği öngörülmektedir. 6360 sayılı Kanun ile büyükşehir ilçe belediyeleri için belirlenen alt nüfus sınırı 20.000 olmasına rağmen, Kahramanmaraş ilinde Ekinözü ve Nurhak ilçeleri bu sınırın altında kalmaktadır. Bu sonuçlar, güney-kuzey ilçeleri arasındaki sosyo-ekonomik ve kültürel farklılıkları daha da artırabilir. En uygun büyüklük açısından bakılırsa Kahramanmaraş’ta hiçbir ilçe büyüklük olarak birbirine benzememekte ve nüfus değerleri çok değişken olmaktadır. Aynı idari ve siyasi yapıya sahip olmasına rağmen birbirleri arasında çok büyük nüfus farklarının olduğu ilçeleri barındırması açısından Kahramanmaraş, büyükşehir belediye kanununun uygulanması sonrasında alan araştırmalarına konu olabilecek bir konumdadır.

Büyükşehir Belediye Kanunu ile Kahramanmaraş belediyeleri arasında değişen görev, yetki ve sorumluluk dağılımının rantabl bir şekilde sürdürülmesi mümkün görülmemektedir. Büyükşehir belediyesinin yükümlü olduğu hizmetlerini sorumlu olduğu bölgelere götürmesinde ilin coğrafi büyüklüğü, topografik çeşitliliği ve mekânsal uzaklığı hizmetlerin kalite ve birim maliyeti kadar hizmetin ihtiyaç olduğu zamanda ulaştırılmasını da etkileyecektir.

Yerel yönetimlerin genel bütçe vergi gelirlerinden alacakları paylarda meydana gelen değişiklikler Kahramanmaraş il geneli için olumlu yansımaktadır. Bununla birlikte hizmet maliyetlerinin arttığı Ekinözü ve Nurhak ilçelerinden meydana gelen bütçe artışları bu bölgelerde ortaya çıkabilecek sorunlara çözüm olacaktır. Ancak bu değişiklikte kalabalık nüfuslu ilçelerden biri olan Elbistan ilçesi olumsuz etkilenmektedir. Bununla birlikte Kahramanmaraş ili ekonomik açıdan yeterli gelişim göstermiş olmasına rağmen sosyo-kültürel açıdan geri kalmış olması büyükşehir belediyesinin yatırımlarının bu noktalara kaymasina neden olacaktır.

6360 sayılı Kanun'da temsil ve katılım açısından yeni bir değişiklik yapılmadığından olumlu yansımaların varlığından söz edilemezken, ancak az nüfuslu belediyelerin lehine bir temsil adaletsizliğinin ortaya çıktığı, bununla birlikte il merkezinde bulunan Dulkadiroğlu ve Onikişubat ilçelerinin büyükşehir belediye meclisinde yeteri kadar temsil edilememe gibi bir soruna yol açtığı da belirtilmelidir. Bununla birlikte kapatılan belde belediyelerinde yaşayanlar açısından temsilci başına düşen kişi sayısında artışlar meydana gelmiş ve bu beldelerin büyükşehir ve ilçe belediye meclisinde temsilleri siyasi partilerin insafina bırakılmıştır. Nitekim Kahramanmaraş'ın büyükşehir olmasıyla belde belediyelerin kapatılarak mahalleye dönüştürülmesi, bu beldelerde yaşayanların temsiline olumsuz yansıyacaktır. Bununla birlikte köylerde alınan kararlara halkın doğrudan katılımına imkân veren köy tüzel kişiliğinin mahalleye dönüştürülmesi, demokratik anlayış açısından olumsuz bir anlam taşımaktadır. 
Yeni Büyükşehir Kanunu ile Kahramanmaraş’ta Yatırım İzleme ve Koordinasyon Başkanlığı kurulmuştur. Yatırım İzleme ve Koordinasyon Başkanlığı'nın sevk ve idaresi vali veya vali tarafından görevlendirilecek bir vali yardımcısı tarafından yerine getirilecektir. Merkezi idare tarafindan yapılan her türlü yardım ve desteğin koordinasyonu, denetimi ve izlenmesi ve acil durumlarda bizzat yerine getirilmesi Yatırım İzleme ve Koordinasyon Başkanlığı tarafından sağlanır. Bu uygulamanın il özel idaresinden çok da bir farkı yoktur. Kısaca büyüksşehir belediye yetkileri ile Yatırım İzleme ve Koordinasyon Başkanlığı’nın yetkileri çakışabilir.

Kahramanmaraş’taki belde ve köyler kırsal alan özellikleri gösterdikleri için kentsel politikalar açısından oluşturulmuş bir büyükşsehir kanunu bu bölgelerin hizmet sunumunda çeşitli sorunların oluşmasına neden olacaktır. $\mathrm{Bu}$ anlamda büyükşehir köyleri ve belde belediyeleri için farklı ancak ölçek ekonomilerini olumsuz etkilemeyecek yeni yönetim birimlerine veya çözümlere ihtiyaç vardır. Bununla birlikte Kahramanmaraş'ın metropoliten alan ya da metropoliten bölge sinıflandırmasında hangi sınıfta olduğu sorusuna şu şekilde cevap verilebilir; metropoliten alan tanımlamasına getirilen ölçütler; nüfus büyüklüğü ve yoğunluğu, tarım dışı alanlarda çalışan iş gücü oranı, sektörlerin kapasiteleri ve ciro oranları, çekirdek şehirle olan bütünleşme düzeyi, çekirdek şehrin diğer şehirler üzerindeki egemenliği ve bağımlılık ilişkisi, toplu taşıma ve ulaşım sistemlerinin gelişmişlik düzeyi, donatılarındaki çeşitlilik ve bölgenin idari kapasitesinin gelişmişliği şeklinde ifade edilirse (Tekel, 2002: 42-43), Kahramanmaraş'ın bu özellikleri sağlayamadığı ve metropoliten alan olarak nitelendirilemeyeceği anlaşılmaktadır. Bununla birlikte metropoliten alan tanımına uymayan ancak büyükşehir statüsüne alınmış şehirler için metropoliten bölge kavramı ortaya atılabilir. Metropoliten bölgede bir veya daha fazla çekirdek şehir bulunabilir. Metropoliten alan içinde kırsal/kentsel politika konuları kentsel yayılma içerir ve şehir, kasaba ve köylerin birleştirilmesi ile oluşur. Bunun yanında metropoliten alanın etki alanı kentsel alandır. Metropoliten bölge de ise bir veya birkaç çekirdek şehir bulunur, kırsal/kentsel ilişkiler daha az yoğundur. Metropoliten bölge içerisinde kentsel hizmetler ile kırsal kaynaklar tamamlayıcılık fonksiyonu görmektedir (Kelling, http://www.eurometrex.org, 2013). Bu ölçüt ve tanımlamalardan hareketle Kahramanmaraş'ın metropoliten bölge özelliği gösterdiğini söyleyebiliriz. Öte yandan yerel yönetimlerde yetki, kaynak ve ölçek büyüklüğünü artıralım anlayışına dayanılarak yapılan yönetsel dönüşümle bütünşehir/büyükşehir düzenlemesi ile ilin coğrafi/mülki sınırlarına taşınması bölgesel yönetim tartışmalarını da beraberinde getirecektir.

Sonuç olarak Kahramanmaraş 6360 sayılı Kanun ile birlikte büyükşehir belediyesi statüsü kazanmış olup Kahramanmaraş il merkezi içerisinden iki büyükşehir ilçe belediyesi oluşturulmuştur. 52 belde ve 476 köy tüzel kişiliği kaldırılarak mahalleye dönüştürülmüştür. Kahramanmaraş ilinde 62 olan belediye sayısı 12 'ye düşmüş ve idari değişikliğe bağli olarak sınır değişiklikleri meydana gelmiştir. Dulkadiroğlu ilçesine; Kahramanmaraş şehrinin 43 mahallesi, Merkez ilçeye bağlı 1 belde belediyesi ve 48 köy ve Pazarcık'a bağlı 9 köy bağlanmıştır. Onikişubat ilçesine Kahramanmaraş şehrinin 47 mahallesi ve Merkez ilçeye bağl1 10 belde belediyesi ve 71 köy bağlanmıştır. Bu düzenleme ile Pazarcık ilçesinin Kelebişler, Bayramgazi ve Cennetpınarı köyleri ise Türkoğlu ilçesine bağlanmış ve idari sınırlar değişmiştir. Bu dönüştürme ya da kapatılma olgusu 30 Mart 2014 yerel seçimleri sonrası uygulanacağı için uygulama sonrası ortaya çıkacak sorunların neler olacağı ve bu sorunlara ilişkin çözüm önerilerinin belirlenmesi yapılacak olan alan çalışmaları ile belirlenebilecektir. 


\section{KAYNAKÇA}

AK PARTİ YEREL GENEL MERKEZİ YEREL YÖNETIMMLER BAŞKANLIĞI, (2012). Sorular ve $\begin{array}{lllll}\text { Cevaplarla } & \text { Yeni } & \text { Büyükşehir } & \text { Belediye }\end{array}$ (www.akparti.org.tr/upload/documents/akparti_buyuksehir_yasasi.pdf)

ARIKBOĞA, E., (2007a). “Türk Yerel Yönetim Sisteminde Reform ve Yeni Kamu Yönetimi”, Kamu Yönetimi Yazıları, B. Eryılmaz, M. Eken, M. L. Şen (Der.), Nobel Yayınları, ss. 42-70.

ARIKBOĞA, E., (2007b.) "Yerel Yönetimlerde Ölçek Sorunu ve Belediye Reformu”, V. Kaтu Yönetimi Forumu (18-20 Ekim 2007), Umuttepe, Kocaeli.

ARIKBOĞA E. (2008) "Türkiye'de Belediyelerin Büyüklüğ̈̈ ve Kentin Bütünlüğü Sorunu: Reform ve Uygulama Analizi”, (Ed. F. Neval Genç, Abdullah Yılmaz, Hüseyin Özgür) "Dönüşen Kentler ve Değişen Yerel Yönetimler içinde”, Gazi Kitabevi, Ankara, s. 299-330.

ARIKBOĞA E., (2009), "Ölçek Reformunun Büyükşehir Belediye Meclislerindeki Temsil Adaletine Olumlu Etkileri”, 4. Ulusal Yerel Yönetimler Sempozyumu, 2009, TODAİE, s. 737-754

ARIKBOĞA E. (2013), "Geçmişten Geleceğe Büyükşehir Belediye Modeli”, (Ed. M.AKif ÇUKURÇAYIR) "Yerel Politikalar Akademik Araştırma ve Düşünce Dergisi”, Ocak/Haziran 2013 s. 48-96

ATMACA T. (2013), “Optimal Belediye Büyüklüğ̈̈ ve Yeni Büyükşehir Belediye Yasası”, Çankırı Karatekin Üniversitesi İktisadi ve İdari Bilimler Fakültesi Dergisi Y.2013, Cilt 3, Sayı 2, ss.168-184

CANPOLAT H. (2010), “Türk Yerel Yönetim Sisteminde Ölçek Reformları ve 5747 Sayılı Kanunla İlgili Yargı Kararlarının Değerlendirilmesi”, Türk İdare Dergisi, S.467 (Haziran 2010), s.79-113.

Kahramanmaraş Çevre ve Şehircilik İl Müdürlüğü, (2011), Kahramanmaraş İli Çevre Durum Raporu, ÇED Hizmetleri ve Çevre İzinleri Şube Müdürlüğü, Kahramanmaraş.

DEMIRCAN S.E. (2008), "Yeni Ekonomik Düzende Küreselleşme Yerelleşme Bağlamında Belediyelerde Yeni Mali Yönetim Anlayışı", Erciyes Üniversitesi iktisadi ve idari Bilimler Fakültesi Dergisi, Sayı: 30, Ocak-Haziran 2008, ss.99-128

DİNÇER B., ÖZASLAN M. ve KAVASOĞLU T., (2003). İllerin ve Bölgelerin Sosyo-Ekonomik Gelişmişslik Sıralaması Araştırması (2003), Devlet Planlama Teşkilatı, Ankara,

ERAYDIN, K., GÜL, E., ÇEVIK, B., DEMİR, E. (2012), Türkiye'de Illlerin gelişmişlik Düzeyi Araştırması, İş Bankası İktisadi Araştırmalar Bölümü.

ERKUL, H., 2010. Türkiye'de Yerel Yönetimler, Detay Yayıncılık, Ankara, 210 s.

EKER, F., (2013), "Kahramanmaraş'ın Tarihi Coğrafyasına Bir Bakış”, KSÜ Sosyal Bilimler Dergisi, Cilt:10, Sayı:2, Sayfa:25-38, Kahramanmaraş.

GOOGLE Haritalar, https://maps.google.com , (E.T. 12.03.2014)

GÜNGÖR, H., (2013). "Yeni Büyükşehir Yönetimi ve Geçiş Nedenleri”, KAYSEM-8 Kuramdan Uygulamaya Yerel Yönetimler ve Kentsel Politikalar Bildiri Kitabı. 
GÜRBÜZ, M., SANDAL, E.K. ve KARABULUT, M. (2004). "Kahraman Maraş'ın Kuruluşu, Gelişimi ve Mekansal Analizi", Kentsel Ekonomik Araştırmalar Sempozyumu, DPT ve Pamukkale Üniversitesi, 1, ss.276-285.

GÜRBÜZ, M., (2012), "Kahramanmaraş Ilinin Genel Çoğrafi Özellikleri ve Turizm Potansiyeli”, (Ed. İlyas Gökhan, Mesut Akben, Kemalettin Koç), "Kahramanmaraş Kültürü”, KSU Kahramanmaraş ve Yöresi Kültür Değerlerini Araştırma ve Uygulama Merkezi, s. 127-214

GÜRBÜZ, M., (2013), Kahramanmaraş Büyükşehir Belediye Sinırları İçerisindeki Yerleşmelerin Fonksiyonel Özellikleri, KSÜ Sosyal Bilimler Enstitüsü Kamu Yönetimi Ana Bilim Dalı, Basılmamış Yüksek Lisans Projesi, Kahramanmaraş.

GÜVEN H. S. (1982) “Değişen Yerel Hizmet Kavramı ve Yerel Yönetimlerde Ölçek Sorunu” Amme İdaresi Dergisi, C: 15, Sayı: 4, (Aralık 1982), s. 27-48

Harita Genel Komutanlığ1, http://www.hgk.msb.gov.tr/, (E.T. 20.03.2013).

IZCI, F. ve TURAN, M., (2013). “Türkiye'de Büyükşehir Belediyesi Sistemi ve 6360 Sayılı Yasa İle Büyükşehir Belediyesi Sisteminde Meydana Gelen Değişimler: Van Örneği”, Süleyman Demirel Üniversitesi İktisadi ve İdari Bilimler Fakültesi Dergisi, 18 (1), ss.117-152.

KARAGEL H. (2012) “Çoğrafi yerellik ve Şehirleşme İlişkisi Bakımından Türkiye'de Büyükşehir Olgusunun Çoğrafi Analizi” UJES 2012, III. Ulusal Jeomorfoloji Sempozyumu, Hatay.

Kahramanmaraş İl Tarım Müdürlüğü, (2006), “Kahramanmaraş Tarım Master Planı”,

Kahramanmaraş Ticaret ve Sanayi Odası http://www.kmtso.org.tr, (E.T. 08.03.2014)

Kalkınma Bakanlığı, http://www.kalkinma.gov.tr,

KELLING J. "Urban-Rural Relationships in Metropolitan Areas of Influence" http://www.eurometrex.org, (E.T.:28.03.2013).

KIZILBOĞA R. ve ÖZASLAN K., 2013. "Il Özel İdaresi ile Yatırım İzleme ve Koordinasyon Başkanlığının İncelenmesi”, (Ed. Yakup Bulut, Veysel Eren, Sedat Karakaya, Abdullah Aydın), Kuramdan Uygulamaya Yerel Yönetimler ve Kentsel Politikalar, Pegem Akademi, Ankara, s. 780-789

KORKMAZ, H., 2001, Kahraman Maraş Havzası'nın Jeomorfolojisi, Kahraman Maraş Valiliği, İl Kültür Müdürlüğü Yayınları No:3, Kahraman Maraş.

KOYUNCU E., "Yenilenen Yerel Yönetim Sisteminde Belediye ve Il Özel İdarelerinin Genel Bütçe Gelirlerinden Alacakları Payların Karşılaştırmalı Analizi”, Kasım 2012, TEPAV

ÖKMEN M. ve Parlak B. (2013), "Kuramdan Uygulamaya Yerel Yönetimler İlkeler Yaklaşımlar ve Mevzuat”, Orion Kitabevi, Ankara.

ÖZGÜR H. "Metropoliten Alanların Yönetimine Kamu Tercihi ve Klasik (Metropoliten Reform) Yaklaşımlarının Bakışları ”Yerel Siyaset Dergisi Haziran 2008, Sayı 30

URAK, http://www.urak.org, E.T. 04.03.2014

USTA E., “Yerel Yönetimlerde Mali bă̆ımlılık Sorunu” DPT, Yerel Yönetimler Forumu, 15 Eylül 2010 
TEKEL A. "Metropoliten Planlamanın Önemi ve Gerekliliği Üzerine" Çağdaş Yerel Yönetimler Dergisi, C: 11 Sayı: 1 (Ocak 2002) s.42-55.

TEPAV, http://www. tepav.org. tr. E.T. 10.03.2014

TOPAL A.K. (2005), “Optimal Yerel Yönetim Büyüklügüne Kuramsal Yaklaşım”, (Ed. H. Özgür \& M. Kösecik), "Yerel Yönetimler Üzerine Güncel Yazılar- I”, s. 449-470.

Türkiye İstatistik Kurumu, http://www.tuik.gov.tr , E.T. 12.03.2014

6360 Sayılı On Üç ilde Büyükşehir Belediyesi ve Yirmi Altı İlçe Kurulması ile Bazı Kanun ve Kanun Hükmünde Kararnamelerde Değişiklik Yapılmasına Dair Kanun

5779 sayılı İl Özel İdarelerine ve Belediyelere Genel Vergi Gelirlerinden Pay Verilmesi Hakkında Kanun

5216 Sayılı Büyükşehir Belediye Kanunu 